OPEN ACCESS

Edited by:

Sandip D. Kamath, James Cook

University, Australia

Reviewed by:

Wayne Robert Thomas, University of

Western Australia, Australia

Geoffrey Mueller, National Institute of

Environmental Health Sciences

(NIEHS), United States

Anna Pomés, Indoor Biotechnologies, United States

*Correspondence:

Rudolf Valenta

Rudolf.valenta@meduniwien.ac.at Baoging Sun

sunbaoqing@vip.163.com

Specialty section:

This article was submitted to Vaccines and Molecular Therapeutics,

a section of the journal

Frontiers in Immunology

Received: 02 June 2021

Accepted: 21 July 2021

Published: 27 August 2021

Citation:

D'souza N, Weber M, Sarzsinszky E, Vrtala S, Curin M, Schaar M, Garib V. Focke-Tejkl M, Li Y, Jones R, Chen $\mathrm{H}$,

Valenta $R$ and Sun $B$ (2021) The

Molecular Allergen Recognition Profile in China as Basis for AllergenSpecific Immunotherapy.

Front. Immunol. 12:719573. doi: 10.3389/fimmu.2021.719573

\section{The Molecular Allergen Recognition Profile in China as Basis for Allergen- Specific Immunotherapy}

\author{
Nishelle D'souza ${ }^{1}$, Milena Weber ${ }^{1}$, Eszter Sarzsinszky ${ }^{1}$, Susanne Vrtala ${ }^{1}$, Mirela Curin ${ }^{1}$, \\ Mirjam Schaar ${ }^{1}$, Victoria Garib ${ }^{1}$, Margarete Focke-Tejkl ${ }^{1}$, Yanqiu $L^{2}{ }^{2}$, Richard Jones ${ }^{2}$, \\ Hao Chen ${ }^{3}$, Rudolf Valenta ${ }^{1,4,5,6 *}$ and Baoqing Sun ${ }^{3 *}$ \\ 1 Division of Immunopathology, Department of Pathophysiology and Allergy Research, Center for Pathophysiology, \\ Infectiology and Immunology, Medical University of Vienna, Vienna, Austria, 2 Worg Pharmaceuticals, Hangzhou, China, \\ ${ }^{3}$ Department of Allergy and Clinical Immunology, State Key Laboratory of Respiratory Disease, National Clinical Research \\ Center for Respiratory Disease, Guangzhou Institute of Respiratory Health, First Affiliated Hospital of Guangzhou Medical \\ University, Guangzhou, China, ${ }^{4}$ Laboratory of Immunopathology, Department of Clinical Immunology and Allergology, \\ Sechenov First Moscow State Medical University, Moscow, Russia, ${ }^{5}$ National Research Center (NRC) Institute of \\ Immunology Federal Medico-Biological Agency (FMBA) of Russia, Moscow, Russia, ${ }^{6}$ Karl Landsteiner University of Health \\ Sciences, Krems, Austria
}

Approximately $30 \%$ of the world population suffers from immunoglobulin-E (IgE)-mediated allergy. IgE-mediated allergy affects the respiratory tract, the skin and the gastrointestinal tract and may lead to life-threatening acute systemic manifestations such as anaphylactic shock. The symptoms of allergy are mediated by lgE-recognition of causative allergen molecules from different allergen sources. Today, molecular allergy diagnosis allows determining the disease-causing allergens to develop allergen-specific concepts for prevention and treatment of allergy. Allergen-specific preventive and therapeutic strategies include allergen avoidance, vaccination, and tolerance induction. The implementation of these preventive and therapeutic strategies requires a detailed knowledge of the relevant allergen molecules affecting a given population. China is the world's most populous country with around 1.4 billion inhabitants and an estimated number of more than 400 million allergic patients. Research in allergy in China has dramatically increased in the last decade. We summarize in this review article what is known about the dominating allergen sources and allergen molecules in China and what further investigations could be performed to draw a molecular map of IgE sensitization for China as a basis for the implementation of systematic and rational allergen-specific preventive and therapeutic strategies to combat allergic diseases in this country.

Keywords: allergy, molecular diagnosis, IgE, AIT = allergen-specific immunotherapy, allergen, allergy vaccine

\footnotetext{
Abbreviations: IgE, Immunoglobulin E; sIgE, specific IgE; IgG, Immunoglobulin G; IU, International Unit; ISU, ISAC standardized unit; ISAC, Immuno-Solid phase Allergy Chip; ELISA, Enzyme-linked immunosorbent assays; ABPA, Bronchopulmonary aspergillosis; Af, Aspergillus fumigatus; ALA, alpha lactalbumin; BLG, beta lactoglobulin; CAS, casein; SPT, skin prick test; PR10, pathogenesis-related protein family 10; LTP, lipid transfer protein; GST, glutathione S transferase; CCD, cross-reactive carbohydrate determinants; Bla g, Blatella germanica; Amb a, Ambrosia artemisifolia; AIT, allergenspecific immunotherapy; HDM, house dust mite; Der p, Dermatophagoides pteronyssinus; Blo t, Blomia tropicalis; Pen m, Penaeus monodon; Cha f, Charybdis feriatus; Ara h, Arachis hypogaea; Art v, Artemisia vulgaris; Phl p, Phleum pratense; Cyn d, Cynodon dactylon; SCIT, Subcutaneous ImmunoTherapy; CRD, Component Resolved Diagnosis; SPT, Skin Prick Test.
} 


\section{INTRODUCTION}

\section{Allergy and Its Evolution in Childhood}

Immunoglobulin E (IgE) - associated allergy is the most frequent immunologically mediated hypersensitivity disease affecting more than $30 \%$ of the world's population. Allergic patients suffer from a variety of clinical symptoms which include hay fever (i.e., rhinitis, conjunctivitis), asthma, skin inflammation (e.g., urticaria, atopic dermatitis), gastrointestinal allergy (e.g., oral allergy syndrome-OAS, vomiting, diarrhea) and lifethreatening systemic anaphylactic shock (1). Of note, allergic patients may suffer from isolated allergic symptoms in certain organs (i.e., monomorbidity) or from various allergic comorbidities affecting several different organs at the same time and thus present with different allergic phenotypes which may also vary over time (2). The detailed analysis of the evolution of allergic sensitization from early childhood to adolescence suggests that allergic sensitizations occur early in life and, depending on genetic and environmental factors, in particular in response to repeated allergen contact, progress from clinically silent forms of IgE sensitizations which are characterized by the presence of low levels of allergen-specific IgE antibodies in the blood without accompanying symptoms towards symptomatic allergy $(3,4)$. The analysis of molecular IgE sensitization profiles in birth cohorts has shown that asymptomatic IgE sensitization frequently precedes symptomatic allergy which then starts with mild symptoms such as allergic rhinitis and consecutively progresses to severe forms such as allergic asthma (5-7). Therefore, allergy may be compared with major diseases affecting mankind such as cancer, cardiovascular diseases, autoimmune diseases, metabolic/endocrine diseases (e.g., Diabetes) which start in a clinically silent form which can only be detected by preventive medical examination through laboratory analyses in phenotypically still "healthy" subjects.

\section{The Importance of Early Allergen-Specific Prevention Taking Local Sensitization Profiles Into Account}

Similar as for all the aforementioned non-communicable diseases which heavily affect mankind and create a huge burden to the health care systems, early preventive intervention strategies are needed for allergy. Only the introduction of preventive measures and in particular of early vaccination holds the promise that they will lead to more effective treatment and thus save huge health care costs. In the case of allergy, preventive strategies include mainly allergen-specific forms of prevention, i.e., allergen avoidance and allergy vaccination, i.e., allergenspecific immunotherapy, AIT (8-12). Regarding the detection of early asymptomatic IgE sensitization in childhood and the consecutive development of allergic manifestations much has been learned in birth cohort studies conducted in a European Union-funded research program (Mechanisms of the Development of Allergy MeDALL) (1). A particular strength of the MeDALL project was that it enabled to study the molecular IgE sensitization profiles in birth cohorts with the MeDALL chip which contained a large number of micro- arrayed allergen molecules (13). This allowed to study the evolution of molecular IgE sensitization from early childhood to adolescence in the longitudinal studies and to understand the variations of regional IgE sensitization profiles in cross-sectional studies involving patients from different regions of a particular country. For example, it could be demonstrated that molecular IgE sensitization profiles are determined by the exposome (i.e., the occurrence of particular allergen sources in certain regions) demonstrating that climate conditions and certain habits in a population have effects on allergen exposure and consequently on allergen sensitization profiles in the population. One of the early studies performed with recombinant birch pollen allergens in different regions of Europe reported strikingly different frequencies of $\operatorname{IgE}$ sensitizations to the major birch pollen allergen Bet $\mathrm{v} 1$ and cross-reactive birch pollen allergens from North to South-Europe (14) and variations of weed allergenspecific IgE sensitization profiles were reported for different European regions and the United States (15). A study conducted in different regions of France exemplified the dependence of molecular IgE sensitization profiles on climate conditions (16). Another study analyzing the molecular IgE sensitization profile of allergic patients from the Philippines demonstrated that symptomatic allergy was caused mainly by house dust mite and pet allergens whereas grass pollen-specific IgE sensitization was mainly due to IgE to carbohydrate epitope-bearing allergens such as Phl p 4 and Cyn d 1 which did not cause allergic symptoms (17). In fact, IgE sensitization to carbohydrate epitopes usually does not lead to clinical symptoms of allergy (18-20).

Interestingly, changes of the exposome by anthropologic as well as natural changes in the biome may have effects on $\operatorname{IgE}$ sensitization profiles in a population already from one to another generation (21).

\section{China as Model for Allergen-Specific Prevention}

In China, the country with the largest population of around 1.4 billion, allergy research has made rapid progress in the last decade. Figure 1 shows the numbers of publications which can be retrieved from PubMed under the terms "Allergy", "Allergen" and "China" from the years 2007 to 2020. The annual number of publications including the three keywords increased from 40 to more than 250 in this period indicating the interest in the disease-causing allergens. In fact, the territory inhabited by a mainly Chinese population covers an area of approximately 9.6 million square kilometers and is the second-largest country in the world by land area after Russia (Figure 2). The territory inhabited by the Chinese population lies between latitudes $18^{\circ}$ and $54^{\circ}$ North and longitudes $73^{\circ}$ and $135^{\circ}$ East comprising a vast and diverse landscape from the Gobi and Taklamakan Desert in the arid north to the subtropical forests in the wet south. We have indicated the diversity of the different climate areas of the territory inhabited by the Chinese population in Figure 2 according to the Köppen-Geiger climate classification system which is summarized in Table $\mathbf{1}(22,23)$. The different climate types are indicated by a combination of a first letter 


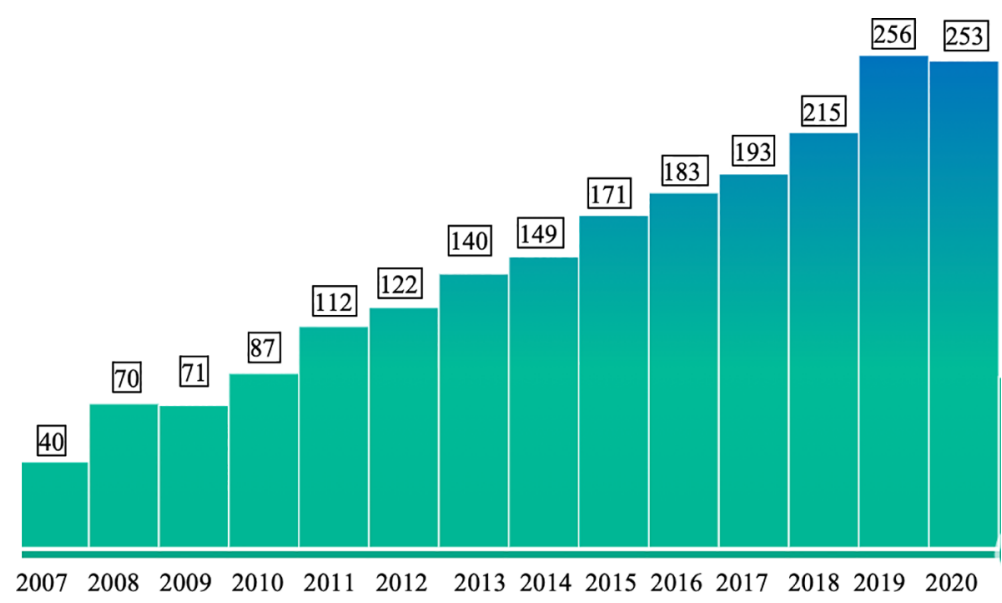

FIGURE 1 | Numbers of publications per year (y-axis) from 2007 to 2020 (x-axis) which can be retrieved from PubMed (https://pubmed.ncbi.nlm.nih.gov/) with the keywords "Allergy" and "Allergen" and "China".

indicating tropical, arid, temperate, continental, or polar climate and additional one or two letters as indicated in Table 1. Due to the occurrence of many different climate areas, China has over 34.000 species of animals and vascular plants making it the thirdmost biodiverse country in the world. Accordingly, one must assume that many different allergen sources and allergen molecules thereof are responsible for allergic sensitizations in different parts of the country.

In order to understand what is known regarding the role of different allergen sources and allergen molecules in the territory inhabited by the Chinese population we have reviewed scientific studies performed in this area to analyze allergic sensitization profiles.

\section{FREQUENCIES OF ALLERGIC SENSITIZATIONS TO ALLERGEN SOURCES IN CHINA: FIRST INFORMATION FROM ALLERGEN EXTRACT-BASED STUDIES}

In the last ten years several studies have been performed to identify relevant allergen sources in the Chinese area. We have summarized in Table 2 studies performed by skin testing with allergen extracts, IgE serology using allergen extracts or by questionnaires (24-36). Table 2 indicates the regions where the studies had been performed, the climate prevailing in the region, what subjects (e.g., general population, patients with allergic symptoms, etc.) were tested, what type of tests had been used (sIgE serology, skin prick testing, questionnaire) and what was considered a positive test result. Importantly, we list what types of allergen extracts had been tested for a better understanding of the prevalence of sensitizations to given allergen extracts in the study populations. In this context it is important to understand that frequencies of detected sensitizations can only be compared for the allergen extracts which have been tested in the different studies and regions because the studies vary considerably regarding the selection of tested allergen extracts. Furthermore, it is important to understand that allergen extract-based testing cannot discriminate between genuine sensitization to the given allergen source and between co- and cross-sensitization (37, 38). This information can only be obtained by molecular testing (39-41). It should be also noted that both, skin prick testing (SPT) and IgE serology can only detect sensitization, but the sensitization does not necessarily need to be linked to clinical symptoms. Positive SPT results and sIgE serology results may also occur in subjects without allergic symptoms (42). Yet there are fundamental differences between IgE serology and SPT. The measurement of specific IgE clearly demonstrates that a subject mounts specific IgE antibodies and thus unambiguously confirms the condition of "IgE sensitization". However, certain "allergens" may bind specifically IgE antibodies but do not induce cross-linking of effector cell-bound $\operatorname{IgE}$ and hence do not cause inflammatory reactions. A good example for such "IgE-reactive antigens" without allergenic activity are carbohydrate-containing determinants also termed CCDs which are present as cross-reactive moieties in a large number of unrelated allergen extracts and hence may give "false-positive" IgE test results meaning that for example a subject shows CCDspecific IgE reactivity but no allergic reaction upon contact with the allergen source $(38,43,44)$. In contrast to IgE serology, SPT measures if an allergen extract can induce effector cell (i.e., mast cell, basophil) activation and thus informs if the sensitized subject may experience an allergic reaction to the tested extract. However, whether indeed an allergic reaction by natural allergen exposure occurs cannot be determined by SPT because this may depend on the extent of allergen exposure, epithelial barrier function, levels and clonality of the $\operatorname{IgE}$ response to name a few factors influencing allergen-induced inflammation $(45,46)$. The fact, that SPT and IgE serology are 


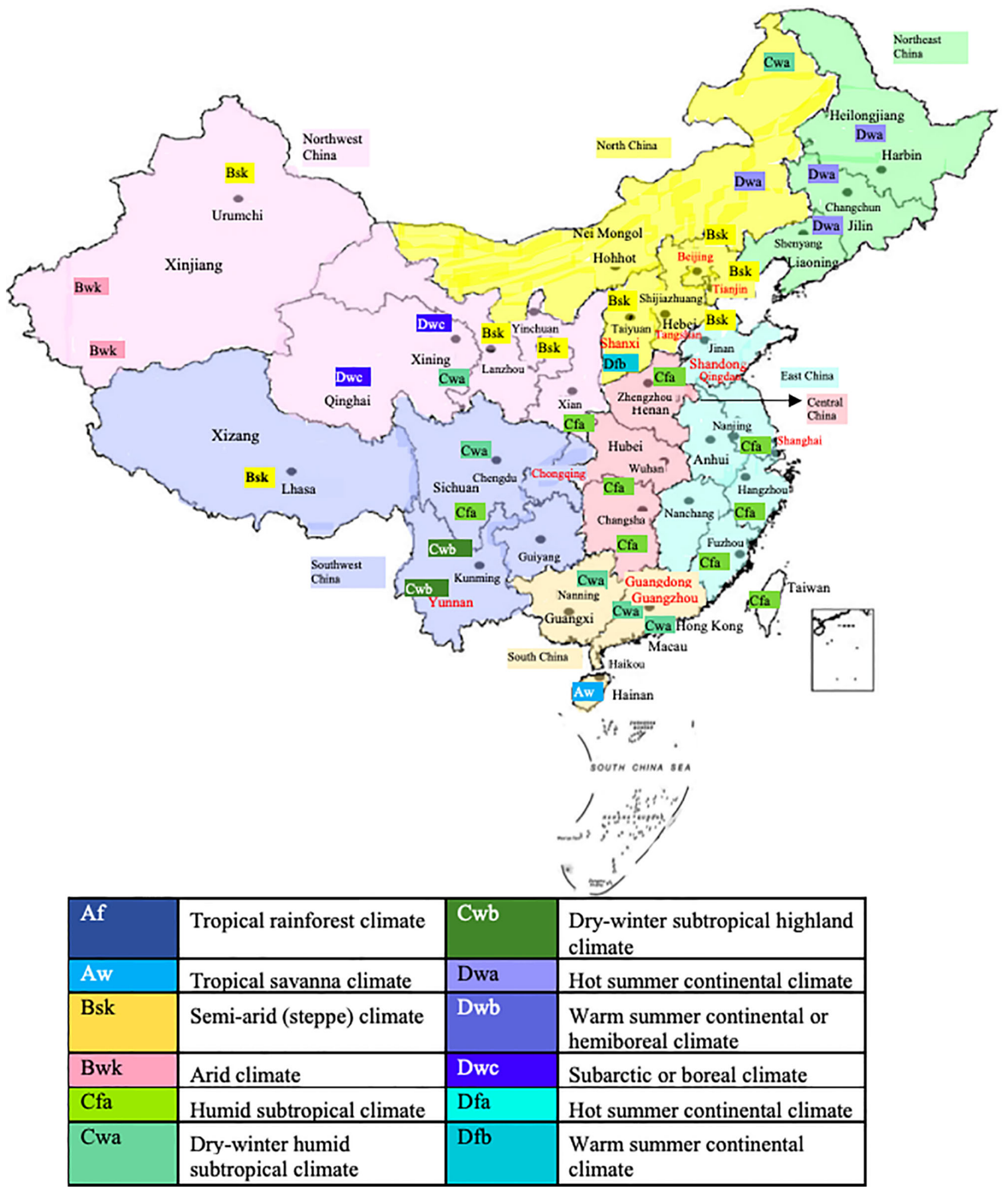

FIGURE 2 | Territories inhabited mainly by a Chinese population and cities/areas for which allergen sensitization data have been obtained. Climate conditions according to the Köppen-Geiger climate classification system are indicated. 
TABLE 1 | Climate classification according to the Köppen-Geiger climate classification system.

\begin{tabular}{|c|c|c|}
\hline $1^{\text {st }}$ letter & $2^{\text {nd }}$ letter & $3^{\text {rd }}$ letter \\
\hline \multirow[t]{4}{*}{ A (Tropical) } & $\mathrm{f}$ (Rainforest) & \\
\hline & m (Monsoon) & \\
\hline & w (Savanna, Dry winter) & \\
\hline & s (Savanna, Dry summer) & \\
\hline \multirow[t]{4}{*}{ B (Arid) } & w (Desert) & \\
\hline & f (Steppe) & \\
\hline & & $\mathrm{H}$ (hot) \\
\hline & & K (Cold) \\
\hline \multirow[t]{6}{*}{ C (Temperate) } & w (Dry winter) & \\
\hline & f (No dry season) & \\
\hline & s (Dry summer) & \\
\hline & & a (Hot summer) \\
\hline & & b (Warm summer) \\
\hline & & c (Cold summer) \\
\hline \multirow[t]{7}{*}{ D (Continental) } & w (Dry winter) & \\
\hline & f (No dry season) & \\
\hline & s (Dry summer) & \\
\hline & & a (Hot summer) \\
\hline & & b (Warm summer) \\
\hline & & c (Cold summer) \\
\hline & & $d$ (Very cold winter \\
\hline \multirow[t]{2}{*}{ E (Polar) } & $\mathrm{T}$ (Tundra) & \\
\hline & F (Eternal frost (ice cap)) & \\
\hline
\end{tabular}

The specification of the climate conditions includes the first, second and third letter as indicated.

not always predicting allergic reactions needs special consideration in food allergy because some food allergens are easily degraded upon uptake in the gastrointestinal tract whereas others are more resistant to degradation, and this cannot be determined by these tests but may require provocation testing such as food provocation (47). Major limitations of allergen extract-based diagnostics are that they do not allow identification of the culprit allergen molecules and that due to poor quality of natural allergen extracts, false positive and negative results can occur (48). All of the aforementioned considerations need to be taken into account when it comes to the interpretation of studies shown in Table 2.

Since the importance of allergen sources may strongly vary depending on climate conditions, we have visualized the centers and the corresponding climate in the region in which the studies had been performed in Figure 2 and in Table 2 .

Various studies on allergen sources were found for several regions of China of which the most surveyed are Yunnan and Guangdong (Figure 2, Table 2) (24, 25) These tropical regions of China inhabit over 150 million of the Chinese population and their unique topography and climate play a great role in the allergens detected in these areas. According to the studies performed, HDM, cockroach and tropical/sub-tropical mites (i.e., Blomia tropicalis) as well as dog and cat represent important respiratory allergen sources in China. Regarding sensitization to pollen and mold allergens there seemed to be considerable variation of sensitization rates. Studies from southern regions of China showed low sensitization rates to pollen and molds of less than $10 \%(24,27)$ whereas a considerable number of pollen and mold-sensitized subjects $>20 \%$ was found in central (33) and eastern parts (34) of China (Table 2). Two multicenter studies should be mentioned because they have analyzed different regions of China and thus allow comparing sensitization rates to the same panel of tested allergen sources in different regions. A study by Sun et al. (26) has investigated 6304 allergic patients from different regions of China by skin testing with a broad panel allergen extract from respiratory allergen sources (Table 2). We have compared the prevalence of IgE sensitization determined in different regions of China according to the latter study (26) in Figure 3. Results obtained demonstrate that the frequencies of HDM, Blomia tropicalis and cockroach sensitization are lowest in North China (Figure 3A) and highest in East and especially South China (Figures 3B-D) By contrast, pollen sensitizations especially to mugwort and ragweed and likewise mold sensitizations were highest in North China (Figure 3A) but lowest in South China (Figure 3C, D). Interestingly the rates of sensitization to dog and cat were comparable in each of the investigated regions (Figures 3A-D). Although the study by Sun et al. (26) was a very large study it does not cover the complete territory inhabited by the Chinese population. Furthermore, sensitization rates may vary by age and may be different in children versus adults.

Another multicenter study was performed by IgE serology in 44156 patients with allergic symptoms by Luo et al. (35) (Table 2). However, this study has tested a different panel of allergen extracts. Instead of weed and grass pollen, only a tree pollen allergen mix was tested, Blomia tropicalis was not included but extracts from milk, crab and shrimp were part of the tested allergen extract panel (Table 2; Figure 4). Nevertheless, this study by Luo et al. (35) conducted in patients with allergic symptoms confirmed the findings of the earlier mentioned SPT study by showing that HDM and cockroach sensitization rates were much lower in Northern China than in Southern China highlighting the Northto-South gradients even more clearly by including data from Central China (Figures 4A-F). Again, the rates of dog sensitization were quite comparable in each of the studied regions, and this was also found for milk sensitization (Figures 4A-F). When comparing sensitization rates determined by SPT and IgE serology we found a good concordance of results for the regions regarding the prevalence of sensitization but we also noted some discrepancies between results. For example, the rates of sensitization determined by SPT for HDM were much higher than those found by IgE serology. These discrepancies may be explained by differences regarding the tested patients, differences in the composition of the allergen extracts used and differences regarding sensitivity and specificity of the used methods (SPT versus IgE serology).

Of note, the rates of sensitization to crab and shrimp were lowest in those regions where HDM and cockroach sensitization was low (i.e., North and Northeast China) and increased towards South China (Figures 4A-F). The latter observation is quite interesting because it is quite possible that $\operatorname{IgE}$ reactivity with cross-reactive allergens found in HDM and cockroach such as tropomyosin and arginine kinase and crab and shrimp may be 
Region

Climate according to Number of subjects

Type of test

Definition of results

$$
\text { system }
$$

Yunnan, $\quad$ Cfb Temperate, no dry 1431 subjects with

Southwest China season, warm summer suspected allergy
Guangdong

South China

Cfa

Temperate, no dry

season, hot summer
Guangzhou,

South China

Various allergy

centers, China
1347 subjects with suspected allergy

\section{Allergen-extract-based} ImmunoCap
Allergen-extract-based slgE levels $\geq 0.35 \mathrm{IU} / \mathrm{mL}$ serology, quantitative, ImmunoCap
Allergen sources tested: d1: house dust mite, Dermatophagoides

Zeng et al. (24)

(ica), tree pollen mix (x $x$ :

Quercus alba, Ulmus americana, Platanus acerifolia, Salix caprea, Populus

deltoides), mold mix (mx1: Penicillium chrysogenum, Cladosporium herbarum,

Aspergillus fumigatus, Alternaria alternata), dog dander (e5), crab (f23), shrimp

(f24), egg white (f1), and milk (f2)

in total $60.9 \%$ were slgE positive

requencies of detected sensitizations were HDM: $44.9 \%$

Cockroach: $26.5 \%$

Tree pollen mix: $21.6 \%$

Mold mix: $4.3 \%$

Dog dander: $5.9 \%$

Crab: $20.8 \%$

Shrimp: $18.7 \%$

Egg white: $13.4 \%$

Milk: $8.5 \%$

Allergen sources tested:

11. house dust mite, Dermatophagoides pteronyssinus), cockroach (16, Blatella

germanica), tree pollen mix (tx4: Quercus alba, Ulmus americana, Platanus

acerifolia, Salix caprea, Populus deltoides), mold mix (mx1: Penicillium

chrysogenum, Cladosporium herbarum, Aspergillus fumigatus, Alternaria alternata), dog dander (e5), crab (†23), shrimp (†24), egg white (f1), and milk (†2) In total $57.8 \%$ were slgE positive

HDM: $43.3 \%$

Cockroach: $20.9 \%$

Tree pollen mix: $5.3 \%$

Mold mix: $3.6 \%$

Dog dander: $4.5 \%$

Crab: $16.3 \%$

Shrimp: $17.4 \%$

Egg white: $13.4 \%$

Milk: $14.8 \%$

Cfa Temperate, no dry

1497 allergic patients

Allergen-extract-based

gE levels $\geq 0.35 \mathrm{IU} / \mathrm{mL}$ ImmunoCap

Results: Der p: $85.50 \%$

Der f: $85.37 \%$

Blo t: $71.54 \%$

Co-sensitized: $70.14 \%$

Several

6304 allergic patients

Skin prick testing with

allergen extracts SPT

Guideline-based skin

Der p: $88 \%$

Per a: $25.7 \%$

Allergen-extract-based American and German Bla g: 18.7\%

cockroach

ImmunoCap lgE

inhibition studies in

1236 sera 
the Köppen-Geiger

Definition of results

Allergen sources tested and percentage of

Reference climate classification system

Southern China Cfa Temperate, no dry 39813 allergic season, hot summer patients

Cfb Temperate, no dry

Yunnan, Southwest China season, warm summer

Southern China Cfa

Temperate, no dry season, hot summer

Shanghai, East China

Cfa

Temperate, no dry season, hot summer

Chongqing, Cwa

Southwest China

Temperate, dry winter, hot summer
Allergen-extract-based slgE levels $\geq 0.35 \mathrm{IU} / \mathrm{mL}$ serology, quantitative, ImmunoCap

were defined as positive.

d1: house dust mite, Dermatophagoides pteronyssinus), cockroach (i6, Blatella

Luo et al. (27)

Results: HDM: $28.1 \%$

Cockroach: $24.3 \%$

Shrimp: $19.2 \%$

Crab: $15.5 \%$

Egg white: $9.9 \%$

Milk: $9.6 \%$

7759 allergic patients

Allergen-extract-based serology, quantitative ImmunoCap

lgE levels $>0.35 \mathrm{IU} / \mathrm{mL}$

Allergen sources tested: $d 1$ : house dust mite Dermatophagoides

Luo et al. (28)

pteronyssinus), cockroach (i6, Blatella germanica), mold mix (mx1: Penicillium

chrysogenum, Cladosporium herbarum, Aspergillus fumigatus, Alternaria

alternata), dog dander (e5), crab (f23), shrimp (f24), egg white (f1), and milk (f2).

In total $45.6 \%$ were slgE positive

Results: Cockroach: 27.0\%

HDM: $25.6 \%$

Mold mix: $3.9 \%$

Dog dander: $3.3 \%$

Shrimp: $18.8 \%$

Crab: $15.6 \%$

Egg white: $9.5 \%$

Milk: $7.4 \%$
1839 children with

spiratory diseases

and cow's milk slgE

Allergen-extract-based

serology, quantitative,

ImmunoCap

7996 allergic patients Skin prick testing with

\begin{abstract}
(axtracts sPT
\end{abstract}

\section{after} allergen extracts SPT

Huang et al.

tested in 103 children:

Results: Cow's milk: $36.7 \%$

ALA: $87.4 \%$

BLG: $86.4 \%$

CAS: $69.9 \%$

wheal size of $\geq 3 \mathrm{~mm}$, Allergen extracts and control solutions were supplied by ALK (Horsholm,

Denmark).

negative control value Results: Dermatophagoides farinae: $73.10 \%$

was considered positive. Dermatophagoides pteronyssinus: $72.21 \%$ Blomia tropicalis: $53.10 \%$

Blattella germanica: $31.18 \%$

Periplaneta americana: $27.75 \%$

dog dander: $24.96 \%$

mixed molds: $17.56 \%$, shrimp: $17.02 \%$

142 allergic children Allergen-extract-based slgE levels $\geq 0.35 \mathrm{IU} / \mathrm{mL} \quad$ Allergen extracts tested: Der $\mathrm{p}$, Der $\mathrm{f}, \mathrm{Blo} \mathrm{t}$, cat dander, dog dander, egg white, Zeng et al. (31) serology, quantitative, were defined as positive. milk, cockroach, shrimp, and crab.

ImmunoCap Results: Der p: 100\%

Der f: $100 \%$

Blo t: $91.84 \%$

Cat: $10.96 \%$,

Dog: $7.32 \%$,

Egg white: $9.15 \%$,

Milk: $11.58 \%$, 


\begin{tabular}{|c|c|c|c|c|c|c|}
\hline Region & $\begin{array}{l}\text { Climate according to } \\
\text { the Köppen-Geiger } \\
\text { climate classification } \\
\text { system }\end{array}$ & Number of subjects & Type of test & Definition of results & $\begin{array}{l}\text { Allergen sources tested and percentage of } \\
\text { positive subjects for each tested source }\end{array}$ & Reference \\
\hline & & & & & $\begin{array}{l}\text { Cockroach: } 17.03 \% \text {, } \\
\text { Shrimp: } 18.90 \% \text {, } \\
\text { Crab: } 18.28 \%\end{array}$ & \\
\hline $\begin{array}{l}\text { Guangdong, } \\
\text { South China }\end{array}$ & $\begin{array}{l}\text { Cfa } \\
\text { Temperate, no dry } \\
\text { season, hot summer }\end{array}$ & 2540 subjects & Questionnaire & $\begin{array}{l}\text { Positive answer } \\
\text { checked by clinician }\end{array}$ & $\begin{array}{l}\text { Total food allergy prevalence rate } 4 \% \\
\text { Detailed results: shrimp: } 4.4 \% \\
\text { crab: } 3.2 \% \\
\text { mango: } 2.3 \% \\
\text { cow's milk and dairy products: } 1.9 \% \\
\text { eggs: } 1.4 \%\end{array}$ & Zeng et al. (32) \\
\hline $\begin{array}{l}\text { Shanghai, East } \\
\text { China }\end{array}$ & $\begin{array}{l}\text { Cfa } \\
\text { Temperate, no dry } \\
\text { season, hot summer }\end{array}$ & $\begin{array}{l}3479 \text { asthmatic } \\
\text { children }\end{array}$ & $\begin{array}{l}\text { Skin prick testing with } \\
\text { allergen extracts SPT }\end{array}$ & $\begin{array}{l}\text { Positive SPT result not } \\
\text { defined }\end{array}$ & $\begin{array}{l}\text { Allergen sources tested: HDM, cat fur, dog fur, ragweed pollen, willow pollen, } \\
\text { shrimp, crab, egg, milk, cashew nut: } \\
\text { HDM: } 51.0 \% \\
\text { cat: } 33.2 \% \\
\text { dog: approx. } 30 \% \\
\text { ragweed: } 37.7 \% \\
\text { willow pollen: approx. } 18 \% \\
\text { shrimp and crab: approx. } 7 \% \\
\text { egg, milk, and cashew nut: each less than } 5 \%\end{array}$ & Mao et al. (33) \\
\hline $\begin{array}{l}\text { Qingdao, East } \\
\text { China }\end{array}$ & $\begin{array}{l}\text { Temperate, dry winter, } \\
\text { hot summer }\end{array}$ & 2841 allergic children & $\begin{array}{l}\text { Retrospective analysis } \\
\text { of Skin prick testing } \\
\text { with allergen extracts } \\
\text { SPT }\end{array}$ & $\begin{array}{l}\text { Ratio of allergen wheal } \\
\text { to histamine wheal of } \\
>26 \% \text { was considered } \\
\text { positive }\end{array}$ & $\begin{array}{l}\text { Allergen extracts tested: Der p, Der f, Penicillium notatum, Aspergillus } \\
\text { fumigatus, late spring flower, summer autumn flower, weed, ragweed, latex, } \\
\text { Gramineae, shrimp, mussel, carp, milk, egg, peanut, peach, eel, hemp, sea } \\
\text { crab } \\
\text { Results obtained for children older than } 6 \text { years: } \\
\text { Der p: } 72.0 \% \\
\text { Der f: } 70.8 \% \\
\text { Penicillium notatum: } 42 \% \\
\text { Aspergillus fumigatus: } 34.3 \% \\
\text { late spring flower: } 39.6 \% \\
\text { summer autumn flower: } 39.6 \% \\
\text { weeds: } 25.3 \% \\
\text { latex: } 28.3 \% \\
\text { Gramineae: } 28 \% \\
\text { mussel: } 38.7 \% \% \\
\text { shrimp: } 38.6 \% \\
\text { carp: } 39 \% \\
\text { milk: } 24.8 \% \\
\text { egg: } 22.1 \% \\
\text { peach: } 20.8 \% \\
\text { eel } 5.7 \% \\
\text { hemp: } 5.4 \% \\
\text { sea crab: } 2.1 \%\end{array}$ & Lin et al. (34) \\
\hline Multicenter & $\begin{array}{l}\text { Four regions, North, } \\
\text { East, Western south, } \\
\text { Southern coast }\end{array}$ & $\begin{array}{l}6304 \text { patients } \\
\text { suffering from asthma } \\
\text { and/or rhinitis }\end{array}$ & $\begin{array}{l}\text { Skin prick testing with } \\
\text { allergen extracts }\end{array}$ & $\begin{array}{l}\text { Wheal size } \geq 3 \mathrm{~mm} \text { after } \\
\text { subtraction of negative } \\
\text { control }\end{array}$ & $\begin{array}{l}\text { Allergen extracts tested: Der p, Der f, Blo t, dog, cat, cockroach (American and } \\
\text { German), Artemisia vulgaris, Ambrosia artemisifolia, mixed grasses, mixed } \\
\text { trees, mold mix I and IV, ALK (Horsholm, Denmark). }\end{array}$ & Sun et al. (26) \\
\hline
\end{tabular}


Region

Climate according to Number of subjects

Type of test system

Figure 3, different

climates

according to

questionnaire

Multicenter,

Several regions

Mainland China Northwest, North,

Northeast, Southwest,

Central, East, South,

different climates

Eastern Taiwan

area

Cfa

Temperate, no dry

season, hot summer 2010-2015
Results for all regions: Der f: 59\%, Der p: $57.6 \%$, Blo t: $40.7 \%$, American

cockroach: 16.1\%, dog: 14\%, German cockroach: 11.5\%, Artemisia vulgaris:

11.3\%, cat: 10.3\%, Ambrosia artemisifolia: $6.5 \%$, mixed mold I: $6.3 \%$, mixed mold IV: $4.4 \%$, mixed grass pollen: $3.5 \%$, mixed tree pollen: $2.2 \%$

Results for each region separately in Figure 3

44156 patients with Allergen-extract-based slgE levels $\geq 0.35 \mathrm{IU} / \mathrm{mL} \quad$ Allergen extracts tested: House dust mite (d1), German cockroach (i6), tree allergic symptoms serology, quantitative, were defined as positive. pollen mix (tx4), mold mix (mx1), dog dander (e5), egg white (f1), cow's milk ImmunoCap (†2), crab (f23), shrimp (†24)

Results: House dust mite: $33.74 \%$, cockroach: $24.5 \%$, shrimp: $19.97 \%$, crab:

$17.31 \%$, cow's milk: $11.62 \%$, egg white: $10.92 \%$

tree pollen mix- $9.35 \%$ dog dander- $4.02 \%$, mold mix: $3.92 \%$

Results for each region in Figure 4

15455 allergic

Allergen-extract-based slgE levels $>0.70 \mathrm{IU} / \mathrm{mL} \quad$ Allergen extracts tested: Der f, Der $p$, cow's milk, egg white, shrimp,

patients (children and serology, quantitative, were defined as positive. cockroach, crab, dog, wheat, ragweed, Candida albicans, yeast, cat, peanut,

adults) seen between ImmunoCap soybean, rice, pork, melon, codfish, egg yolk, Aspergillus fumigatus, A. tenuis, orange, Pencillium notatum

Results adults (>18 years; approximately): Der f: 53\%; Der p: 52\%; cow's milk: 5\%; egg white: $3 \%$; shrimp: $32 \%$; cockroach: $25 \%$; crab: $31 \%$; dog: $22 \%$; wheat: $9 \%$; ragweed: $8 \%$; Candida albicans: $18 \%$; yeast: $6 \%$; cat: $8 \%$; peanut: $5 \%$; soybean: $9 \%$; rice: $3 \%$; pork: $5 \%$; melon: $3 \%$; codfish: $2 \%$; egg yolk: $<1 \%$; Aspergillus fumigatus: $6 \%$; Alternaria alternata: $2 \%$; orange: $<1 \%$; Pencillium notatum: $3 \%$; Results children ( $<18$ years, approximately: Der f: 80\%; Der p: $78 \%$; cow's milk: $32 \%$; egg white: $32 \%$; shrimp: $23 \%$; cockroach: 22\%; crab: $20 \%$; dog: $18 \%$; wheat: $15 \%$; ragweed: $10 \%$; Candida albicans: $9 \%$; yeast: $8 \%$; cat: $7 \%$; peanut: $6 \%$; soy bean: $5 \%$; rice: $3 \%$; pork: $3 \%$; melon: $2.5 \%$; codfish: $2 \%$; egg yolk: $2 \%$; Aspergillus fumigatus: $2 \%$; Alternaria alternata: $1 \%$; orange: $1 \%$; Pencillium notatum: $<1 \%$. 


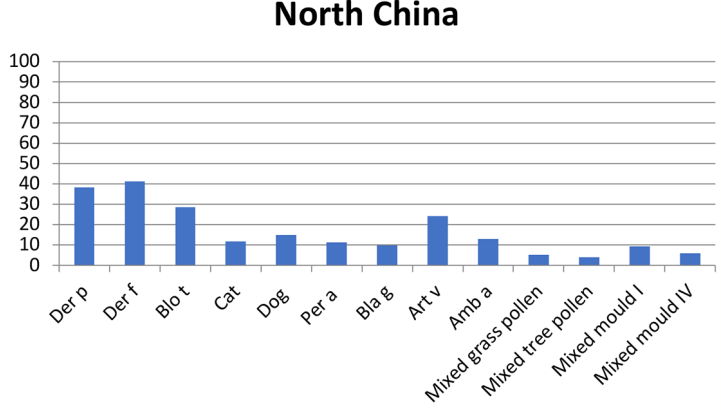

B

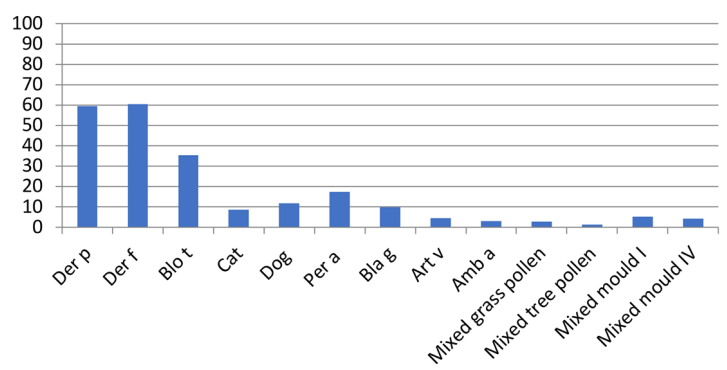

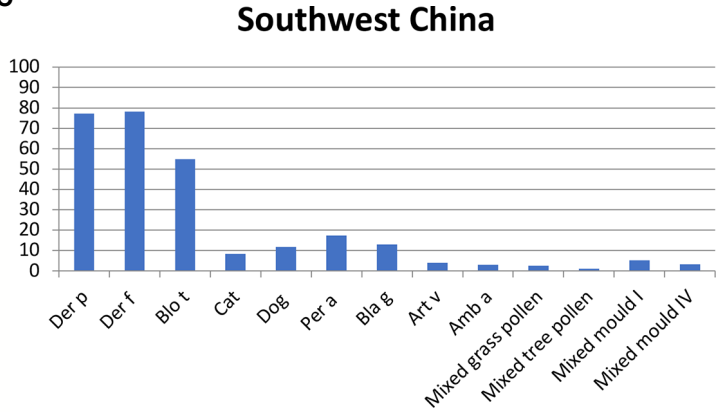

D

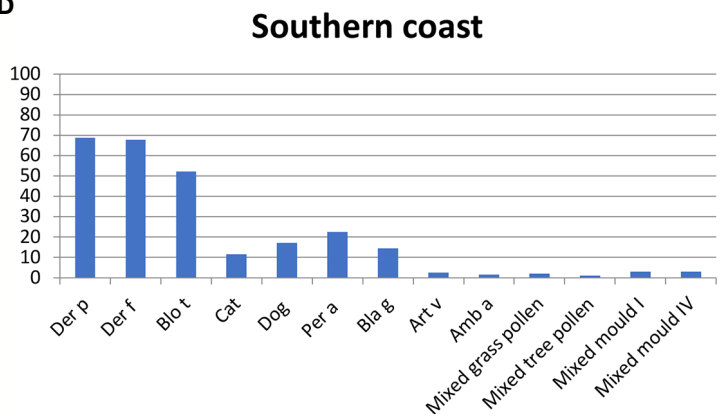

FIGURE 3 | Frequencies ( $y$-axes: percentages of positive subjects) of allergic sensitizations to different allergen extracts according to (26) (x-axes: Der p, Der $\mathrm{f}$, Blo t, cat, dog, Per a, Bla g, Art v, Amb a, mixed grass pollen, mixed tree pollen, mixed mold I and mixed mold IV) as determined by skin prick testing in different areas of China (A): North China; (B): East China; (C): Southwest China; (D): Southern Coast). Depending on the tested region, frequencies of IgE sensitization varied approximately as follows: Der p: 39-78\%; Der f: 40-79\%; Blo t: 28-52\%; cat: 8-12\%; dog: 12-18\%; Per a: 10-22\%; Bla g: 10-12\%; Art v: 3-25\%; Amb a: 2-12\%; mixed grass pollen: 2-7\%; mixed tree pollen: 1-4\%; mixed mold I: 3-10\%; mold IV: 3-7\%.

responsible for the association of the IgE responses between the respiratory and food allergen sources. Accordingly, it was of interest to review data regarding molecular IgE sensitization profiles from China to understand the fine specificities of $\operatorname{IgE}$ sensitization in greater detail.

\section{INFORMATION REGARDING MOLECULAR SENSITIZATION PROFILES IN CHINA THROUGH FIRST STUDIES PERFORMED WITH MOLECULAR DIAGNOSTICS}

When reviewing allergen extracts based studies performed with allergen extracts in China, we noted already that many comprehensive studies including large numbers of subjects had been performed. Most of the studies mentioned in Table 2 enrolled more than 1000 subjects but were limited to serology and therefore further investigations taking clinical parameters are needed. Studies performed in such large numbers of patients have only been performed in certain birth cohort studies in Europe but are lacking for most other parts of the world (49). Likewise, we found that also a considerable number of studies had been performed to analyze the molecular IgE sensitization profiles of patients from different regions of China with purified natural and recombinant allergen molecules (Table 3). Specific IgE reactivity to purified natural and recombinant respiratory and food allergens was analyzed in different regions of China (Table 3) (50-63).

The study by Huang et al. (50), provides interesting information about IgE sensitizations to HDM, Blomia tropicalis and cockroach allergens (Table 3 ). This study confirms the importance of the major HDM allergens, Der p 1, Der p 2 and Der p 23 in a population from South China and shows that Der p 7 and Der p 5 are also quite relevant molecules. Interestingly, the rate of sensitization to Blo t 5 (28\%) was considerably higher than to the related allergen, Der p 5 (15\%) from HDM indicating that Blomia tropicalis may be an independent and important allergen source whereas frequencies of IgE reactivity to Der $\mathrm{p}$ and Der $\mathrm{f}$ allergens were almost identical. IgE sensitization rates to cockroach allergen molecules were low $(<10 \%)$ in the HDM population analyzed by Huang et al. The frequencies of sensitization and importance of Der p 1 and Der p 2 were confirmed in other studies (Table 3) (51, 55). Evidence for IgE cross-reactivity between HDM tropomyosin, Der p 10 and tropomyosins from other invertebrates including food was found by Zeng et al. (55) indicating Der p 10 as the genuinely sensitizing allergen.

The impact of Blomia tropicalis allergens is highly seen in children and there are various data and evidence that show the 


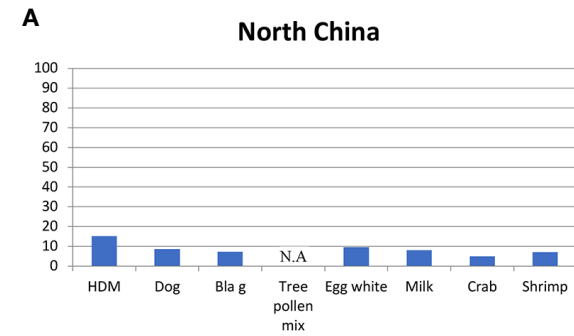

B

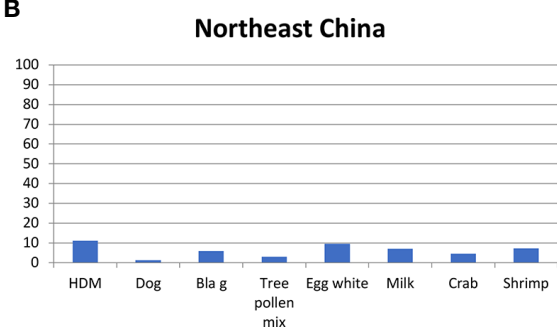

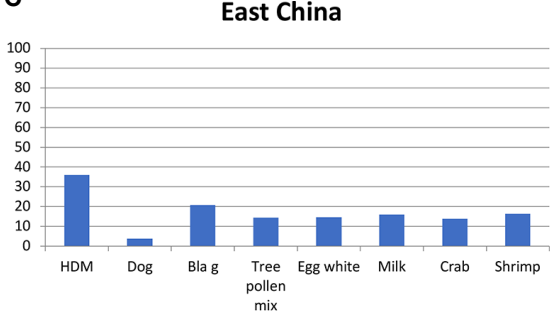

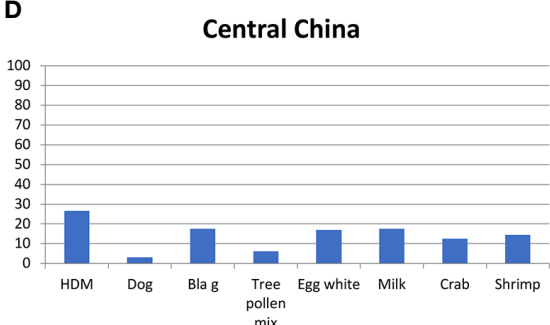

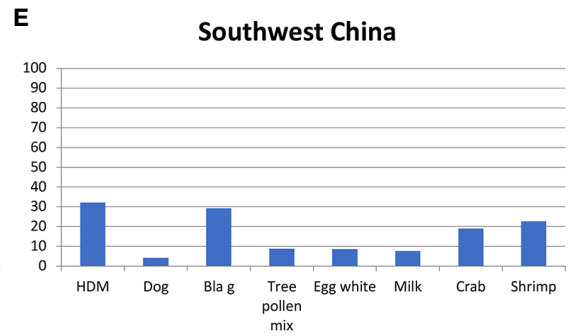

F

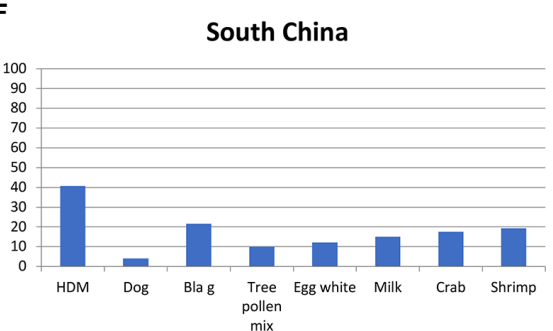

FIGURE 4 | Frequencies (y-axes: percentages of positive subjects) of lgE sensitizations to different allergen extracts according to (35) (X-axes: HDM; dog; Bla g; tree pollen mix; egg white; milk; crab; shrimp) as determined by lgE serology in different areas of China ((A): North China; (B): Northeast China; (C): East China; (D): Central China; (E): Southwest China; (F): South China). Depending on the tested region, frequencies of IgE recognition varied approximately as follows: HDM: 1140\%; dog: 1-9\%; Bla g: 7-30\%; tree pollen mix: 3-14\%; egg white: 8-17\%; milk: 7-18\%; crab: 4-19\%; shrimp: 8-22\%.

health implications of this particular allergen source. While the study performed by Kidon et al. (64), was based in Singapore, over $75 \%$ of the study population were of Chinese origin. Kidon et al. (64) reported $70 \%$ incidence of Blo t allergen sensitization among 253 students and the most prominent allergen molecules were Blo t 5, Blo t 7, Blo t 15 and Blo t 21. The health implications of this allergy can highly vary: some patients have fewer symptoms while others may have upper and lower respiratory tract problems with skin manifestations. Kidon et al. suggest that this may be due to the patient's qualitative allergic sensitization/ responses to perennial allergens in their surroundings. A comparison of sensitization to Blomia and Dermatophagoides in Singapore and China showed large differences and suggests Blo t 5 as marker allergen for accurate discrimination of IgE sensitization to Blomia and Dermatophagoides (64). Accordingly, the sensitization pattern for Chinese people may be dominated by their living environment (65).

The Singapore and China comparison also shows a high reactivity of subjects in China to amylase (Blo t 4) which would be indicative cross reactivity with anti-scabies. China has one of the highest burdens of scabies infections in the world which will have affected at least $20 \%$ of the population and (66) therefore molecular surveys should include binding to the group 4 for current and past infections and group 20 for current infections (67).

Quantitative measurements by ImmunoCAP or micro arrays eventually with basophil activation experiments performed with allergen molecules and not only prevalence data would be critical to determine the allergic load and thus the reagents needed for optimal immunotherapy. For optimal immunotherapy allergen molecules with clinical relevance as reflected by high IgE binding capacity and allergenic activity need to be identified (43).

The molecular analyses summarized in Table 3 provided further interesting insights. For example, in certain parts of southern China grass pollen sensitization seemed to be due to cross-reactive carbohydrates because most grass pollen sensitized patients mainly reacted with $\mathrm{nPhl} \mathrm{p} 4$ and nCyn $\mathrm{d} 1$ whereas only few showed IgE reactivity to the clinically relevant grass pollen allergens such as Phl p 1, Phl p 5, Phl p 6, Phl p 12 (52, 54). Additional studies have been performed in the western and northern parts of China, but results are not yet available. The importance of mugwort pollen allergy was highlighted by several studies identifying Art v 1 and Art v 3 as the most important allergens in terms of frequencies of IgE recognition and allergenspecific IgE levels $(53,59)$. Art an 7 was proposed as an important mugwort allergen but the levels of specific IgE were much lower than those specific for Art $\mathrm{v} 1$ and no recombinant allergen without glycosylation is yet available to inform about the importance of peptide versus carbohydrate epitopes in its $\operatorname{IgE}$ recognition (53). In addition, the importance of cat and dog sensitizations was underlined by the molecular studies identifying especially Fel $\mathrm{d} 1$ and to a lower extent of Can $\mathrm{f} 1$ as important allergens (36). Another interesting finding was that birch pollen allergy as confirmed by IgE reactivity to the major birch pollen allergen, Bet v 1 was found in patients from Beijing and Northern China (60). Bet v 1 patients also suffered from oral allergy syndrome due to cross-reactivity with Bet $\mathrm{v}$ 1-related PR10 allergens from plant food (60). Thus, the possible importance of birch pollen allergy should not be neglected in 
TABLE 3 | lgE sensitization to allergen molecules determined in different regions of China by lgE serology.

\begin{tabular}{|c|c|c|c|c|c|c|}
\hline Region & $\begin{array}{l}\text { Climate according to the } \\
\text { Köppen-Geiger climate } \\
\text { classification system }\end{array}$ & $\begin{array}{l}\text { Number of } \\
\text { subjects }\end{array}$ & Type of test & Definition of results & $\begin{array}{l}\text { Allergen molecules tested and } \\
\text { percentage of positive subjects } \\
\text { for each tested allergen }\end{array}$ & Reference \\
\hline $\begin{array}{l}\text { Guangdong, South } \\
\text { China }\end{array}$ & $\begin{array}{l}\text { Temperate, no dry } \\
\text { season, hot summer }\end{array}$ & $\begin{array}{l}432 \text { mite allergic } \\
\text { patients }\end{array}$ & $\begin{array}{l}\text { EUROIMMUN } \\
\text { system } \\
\text { (EUROIMMUN, } \\
\text { Oumeng } \\
\text { Medical } \\
\text { Laboratory, } \\
\text { Lübeck, } \\
\text { Germany) }\end{array}$ & $\begin{array}{l}\geq 0.35 \mathrm{IU} / \mathrm{mL} \text { were } \\
\text { defined as slgE-pos- } \\
\text { itive. }\end{array}$ & 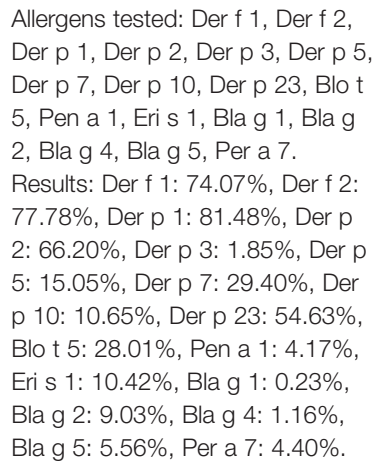 & Huang et al. (50) \\
\hline $\begin{array}{l}\text { Guangzhou, South } \\
\text { China }\end{array}$ & $\begin{array}{l}\text { Cfa } \\
\text { Temperate, no dry } \\
\text { season, hot summer }\end{array}$ & $\begin{array}{l}57 \text { polysensitized } \\
\text { mite allergic } \\
\text { patients }\end{array}$ & $\begin{array}{l}\text { ImmunoCap } \\
\text { Immuno-Solid } \\
\text { phase Allergy } \\
\text { Chip (ISAC) }\end{array}$ & $\begin{array}{l}\text { slgE levels } \geq 0.30 \text { ISU } \\
\text { were classified as } \\
\text { positive. }\end{array}$ & $\begin{array}{l}112 \text { allergen molecules of the } \\
\text { ImmunoCAP Immuno-Solid phase } \\
\text { Allergy Chip (ISAC) (Thermo Fisher } \\
\text { Scientific, Uppsala, Sweden), } \\
\text { Results: nDer f 1: 71.9\%, rDer f 2: } \\
\text { 73.7\%, nDer p 1: 70.1\%; rDer p 2: } \\
\text { 66.7\%; rDer p 10: 10\%, rBlo t 5: } \\
\text { 10\%, rLep d 2: 10\%; rFel d 1: } \\
\text { 29.8\%, rCan f 1: 14\%, nPhl p 4: } \\
\text { 12.3\%, nCyn d 1: 17.5\%, CCD: } \\
\text { 7.0\%, nPen m 1: 8.8\%, nJug r 2: } \\
\text { 8.8\%, nPen m 2: 5.3\%, rAsp f 3: } \\
\text { 8.8\%, rAsp f 1: 7.0\%, rAlt a 1: } \\
\text { 5.3\%, rAsp f 6: 5.3\%, rAlt a 1: } \\
\text { 3.5\%, nBla g 7: 8.8\%, rAni s 3: } \\
\text { 8.8\%. n }\end{array}$ & Hu et al. (51) \\
\hline $\begin{array}{l}\text { Guangzhou, South } \\
\text { China }\end{array}$ & $\begin{array}{l}\text { Cfb } \\
\text { Temperate, no dry } \\
\text { season, Warm summer }\end{array}$ & $\begin{array}{l}258 \text { allergic } \\
\text { patients of whom } \\
58 \text { who were } \\
\text { positive for } \\
\text { Bermuda, timothy } \\
\text { and Humulus } \\
\text { scandens were } \\
\text { tested with allergen } \\
\text { molecules }\end{array}$ & $\begin{array}{l}\text { Allergen- } \\
\text { extract-based } \\
\text { and allergen } \\
\text { component- } \\
\text { based } \\
\text { serology, } \\
\text { quantitative, } \\
\text { ImmunoCap }\end{array}$ & $\begin{array}{l}\geq 0.35 \mathrm{IU} / \mathrm{mL} \text { were } \\
\text { defined as slgE-pos- } \\
\text { itive. }\end{array}$ & $\begin{array}{l}\text { Allergens tested in } 35 \text { timothy- } \\
\text { positive subjects: Phl p 4, Phl p 1, } \\
\text { Phl p 5, Phl p 6, Phl p 7, Phl p 11, } \\
\text { Phl p 12. } \\
\text { Results: Phl p 4: 100\%, Phl p 1: } \\
\text { 17.1\%, Phl p 5: 8.6\%, Phl p 6: } \\
\text { 8.6\%, Phl p 7: 8.6\%, Phl p 11: } \\
\text { 8.6\%, Phl p 12: 8.6\%. }\end{array}$ & Luo et al. (52) \\
\hline \multirow[t]{2}{*}{$\begin{array}{l}\text { Guangdong South } \\
\text { China }\end{array}$} & Cfb & $\begin{array}{l}268 \text { HDM allergic } \\
\text { patients who }\end{array}$ & $\begin{array}{l}\text { Euroimmun } \\
\text { system } \\
\text { (Euroline; }\end{array}$ & $\begin{array}{l}\geq 0.35 \mathrm{IU} / \mathrm{mL} \text { were } \\
\text { defined as slgE } \\
\text { positive. }\end{array}$ & $\begin{array}{l}\text { Positive results with allergen } \\
\text { extracts in the population: Dog } \\
\text { (e1): } 54.85 \% \text {, cat (e2): } 63.81 \% \text {, } \\
\text { cow (e4): } 13.06 \% \text {, sheep (e81: } \\
\text { 10.45\%, rat (e73): } 10.82 \%\end{array}$ & Chen et al. (36) \\
\hline & $\begin{array}{l}\text { Temperate, no dry } \\
\text { season, warm summer }\end{array}$ & $\begin{array}{l}\text { were SPT positive } \\
\text { for cat and/or dog }\end{array}$ & $\begin{array}{l}\text { EUROIMMUN, } \\
\text { Lubeck, } \\
\text { Germany) }\end{array}$ & & $\begin{array}{l}\text { Allergens tested: Can f 1, Can f 2, } \\
\text { Can f 3, Can f 4, Can f 5, Fel d 1, } \\
\text { Fel d 2. } \\
\text { Results: Can f 1: } 17.54 \% \text {, Can f 2: } \\
\text { 7.46\%, Can f 3: } 7.46 \% \text {, Can f 4: } \\
\text { 7.84\%, Can f 5: } 9.70 \%, \text { Fel d 1: } \\
61.19 \%, \text { Fel d 2: } 11.19 \%\end{array}$ & \\
\hline $\begin{array}{l}\text { Shanxi and } \\
\text { Shandong } \\
\text { provinces, North } \\
\text { China and Yunan } \\
\text { province, } \\
\text { Southwestern } \\
\text { China }\end{array}$ & $\begin{array}{l}\text { Dwa Continental, dry } \\
\text { winter, hot summer Cwb } \\
\text { Dry-winter subtropical } \\
\text { highland climate }\end{array}$ & $\begin{array}{l}240 \text { allergic } \\
\text { patients }\end{array}$ & $\begin{array}{l}\text { Allergen- } \\
\text { extract-based } \\
\text { serology, } \\
\text { quantitative, } \\
\text { ImmunoCap }\end{array}$ & $\begin{array}{l}\geq 0.35 \mathrm{IU} / \mathrm{mL} \text { were } \\
\text { defined as slgE } \\
\text { positive. }\end{array}$ & $\begin{array}{l}\text { Allergens tested: nArt v 1, nArt ar } \\
2 \text {, nArt v 3, nArt an } 7 \text { plus } \\
\text { mugwort pollen extract } \\
\text { Results: nArt v 1: } 84 \% \text {, median } \\
\text { slgE: } 9.6 \mathrm{kUA} \mathrm{L} \text {, nArt ar 2: } 48 \% \text {, } \\
\text { median slgE } 0.2 \mathrm{kUA} / \mathrm{L} \text {, nArt v 3: } \\
66 \% \text {, median slgE 1.1kUA/L, nArt } \\
\text { an 7: } 87 \% \text {, median slgE 2.1kUA/L } \\
\text { mugwort pollen: } 100 \% \text {, median } \\
\text { slgE } 30.4 \mathrm{kUA} / \mathrm{L}\end{array}$ & Gao et al. (53) \\
\hline
\end{tabular}


TABLE 3 | Continued

\begin{tabular}{|c|c|c|c|c|c|c|}
\hline Region & $\begin{array}{l}\text { Climate according to the } \\
\text { Köppen-Geiger climate } \\
\text { classification system }\end{array}$ & $\begin{array}{l}\text { Number of } \\
\text { subjects }\end{array}$ & Type of test & Definition of results & $\begin{array}{l}\text { Allergen molecules tested and } \\
\text { percentage of positive subjects } \\
\text { for each tested allergen }\end{array}$ & Reference \\
\hline $\begin{array}{l}\text { Guangzhou, South } \\
\text { China }\end{array}$ & $\begin{array}{l}\text { Temperate, no dry } \\
\text { season, Warm summer }\end{array}$ & $\begin{array}{l}78 \text { patients } \\
\text { sensitized to } \\
\text { Bermuda grass }\end{array}$ & $\begin{array}{l}\text { Allergen- } \\
\text { component- } \\
\text { based } \\
\text { serology, } \\
\text { quantitative, } \\
\text { ImmunoCap }\end{array}$ & $\begin{array}{l}\geq 0.35 \mathrm{IU} / \mathrm{mL} \text { were } \\
\text { defined as slgE } \\
\text { positive. }\end{array}$ & $\begin{array}{l}\text { Allergens tested: Cyn d } 1 \text { (g216), } \\
\text { Cyn d 12, Phl p } 1 \text { (g205), Phl p } 4 \\
\text { (g208), Phl p } 5 \text { (g215), Phl p } 7 \\
\text { (g210), Phl p } 12 \text { (g212), Art v } 1 \\
\text { (w231), Art v } 3 \text { (w233), Art v } 4 \\
\text { (w234). } \\
\text { Results: Cyn d } 1 \text { (g216): 24.4\%, } \\
\text { Cyn d 12: approx. 8\%, Phl p } 1 \\
\text { (g205): 12.8\%, Phl p } 4 \text { (g208): } \\
\text { 7.7\%, Phl p } 5 \text { (g215): approx. 3\%, } \\
\text { Phl p } 7 \text { (g210): approx. 5\%, Phl p } \\
12 \text { (g212): 9.0\%, Art v } 1 \text { (w231): } \\
\text { approx. 6\%, Art v } 3 \text { (w233): } \\
\text { 10.3\%, Art v } 4 \text { (w234): 10.3\%. }\end{array}$ & Liao et al. (54) \\
\hline Southern China & $\begin{array}{l}\text { Temperate, no dry } \\
\text { season, hot summer }\end{array}$ & $\begin{array}{l}200 \text { slgE Der p- } \\
\text { positive patients } \\
\text { with allergic } \\
\text { asthma and/or } \\
\text { rhinitis }\end{array}$ & $\begin{array}{l}\text { Allergen- } \\
\text { component- } \\
\text { based } \\
\text { serology, } \\
\text { quantitative, } \\
\text { ImmunoCap } \\
\text { ImmunoCap } \\
\text { Immuno-Solid } \\
\text { phase Allergy } \\
\text { Chip (ISAC) }\end{array}$ & $\begin{array}{l}\geq 0.35 \mathrm{IU} / \mathrm{mL} \text { were } \\
\text { defined as slgE } \\
\text { positive for quantitative } \\
\text { ImmunoCap and } \geq 0.30 \\
\text { ISU were defined as } \\
\text { slgE positive for ISAC. }\end{array}$ & $\begin{array}{l}\text { All } 200 \text { were tested for IgE to Der } \\
\text { p 1, Der p } 2 \text { and Der p } 10 \text { by } \\
\text { quantitative ImmunoCap and } 75 \\
\text { were tested by ISAC } \\
\text { Results: Der p } 1 \text { and/or Der p 2: } \\
91.5 \% \text {, Der p 10: 6\%. Der p } 10 \\
\text { positives showed also IgE } \\
\text { reactivity to other tropomyosins: } \\
\text { Ani s 3: } 67 \% \text {, Bla g } 7: 67 \% \text {, Pen } \\
\text { m 1: } 75.3 \% \text {. }\end{array}$ & Zeng et al. (55) \\
\hline Northern China & $\begin{array}{l}\text { Dwa Continental, dry } \\
\text { winter, hot summer }\end{array}$ & $\begin{array}{l}48 \text { patients with } \\
\text { milk allergy }\end{array}$ & IgE ELISA & $\begin{array}{l}\text { Mean optical density } \\
\text { values plus two } \\
\text { standard deviations } \\
\text { measured for non-cow' } \\
\text { s milk allergic subjects } \\
\text { were considered as } \\
\text { cut-off for a positive } \\
\text { result }\end{array}$ & 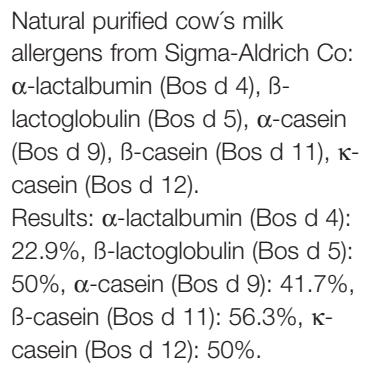 & Li et al. (56) \\
\hline Tianjin, China & $\begin{array}{l}\text { Dwa } \\
\text { Continental, dry winter, } \\
\text { hot summer }\end{array}$ & $\begin{array}{l}56 \text { egg allergic } \\
\text { children }\end{array}$ & $\begin{array}{l}\text { Light-initiated } \\
\text { chemiluniscent } \\
\text { assay (LICA) }\end{array}$ & $\begin{array}{l}\text { Mean relative light units } \\
\text { plus two standard } \\
\text { deviations measured } \\
\text { for non-cow's milk } \\
\text { allergic subjects were } \\
\text { considered as cut-off } \\
\text { for a positive result }\end{array}$ & $\begin{array}{l}\text { Natural purified egg allergens from } \\
\text { Sigma-Aldrich Co: nGal d 1, nGal } \\
\text { d 2, nGal d 3, nGal d 4, nGal d } 5 \text {. } \\
\text { Results: nGal d 1: } 51.8 \% \text {, nGal d } \\
\text { 2: } 62.5 \% \text {, nGal d 3: } 41.1 \% \text {, nGal d } \\
\text { 4: } 14.3 \% \text {, nGal d 5: } 23.2 \% \text {. }\end{array}$ & $\begin{array}{l}\text { Zhang et al. } \\
\text { (57) }\end{array}$ \\
\hline Beijing, China & $\begin{array}{l}\text { Dwa } \\
\text { Continental, dry winter, } \\
\text { hot summer }\end{array}$ & $\begin{array}{l}402 \text { pollinosis } \\
\text { patients }\end{array}$ & $\begin{array}{l}\text { Allergen- } \\
\text { component- } \\
\text { based } \\
\text { serology, } \\
\text { quantitative, } \\
\text { ImmunoCap }\end{array}$ & $\begin{array}{l}\geq 0.35 \mathrm{IU} / \mathrm{mL} \text { were } \\
\text { defined as slgE } \\
\text { positive }\end{array}$ & $\begin{array}{l}\text { Allergens tested: rBet v 1, rBet v } 2 \text {, } \\
\text { Art v 1, Art v 3, Pru p 1, Pru p } 3 \text {. } \\
\text { Results: } 85 \% \text { ( } n=31 \text { ) of birch pollen } \\
\text { allergic patients ( } n=37 \text { ) were } \\
\text { positive for Bet } \vee 1 \text {. Art v } 1 \text { was } \\
\text { more prevalent (i.e., } 79 \% \text { ) in } \\
\text { pollen-food allergic patients than in } \\
\text { pollen allergic patients without } \\
\text { food allergy (i.e., } 33 \% \text { ). IgE } \\
\text { reactivities to Bet } \vee 1 \text { and Pru p } 1 \\
\text { and between Art v } 3 \text { and Pru p } 3 \\
\text { were significantly correlated. }\end{array}$ & Li et al. (58) \\
\hline Beijing, China & $\begin{array}{l}\text { Dwa } \\
\text { Continental, dry winter, } \\
\text { hot summer }\end{array}$ & $\begin{array}{l}148 \text { mugwort } \\
\text { allergic patients of } \\
\text { whom } 107 \text { suffered } \\
\text { also from plant } \\
\text { food allergy }\end{array}$ & $\begin{array}{l}\text { Allergen- } \\
\text { component- } \\
\text { based } \\
\text { serology, } \\
\text { quantitative, } \\
\text { ImmunoCap }\end{array}$ & $\begin{array}{l}\geq 0.35 \mathrm{IU} / \mathrm{mL} \text { were } \\
\text { defined as slgE } \\
\text { positive }\end{array}$ & $\begin{array}{l}\text { Allergens tested: Art v 1, Art v 3, } \\
\text { Pru p 3, Pru p 1, Pru p 4, Ara h 9, } \\
\text { Cor a 8. } \\
\text { Results Art v 1: } 81.1 \% \text {, Art v 3: } \\
\text { 73.0\%, Pru p 3: } 90 \% \text { of peach } \\
\text { allergic patients ( } \mathrm{n}=88 \text { ), Ara h 9: } \\
88 \% \text { of peanut allergic patients }\end{array}$ & $\begin{array}{l}\text { Deng and Yin } \\
\text { (59) }\end{array}$ \\
\hline
\end{tabular}


TABLE 3 | Continued

\begin{tabular}{|c|c|c|c|c|c|c|}
\hline Region & $\begin{array}{l}\text { Climate according to the } \\
\text { Köppen-Geiger climate } \\
\text { classification system }\end{array}$ & $\begin{array}{l}\text { Number of } \\
\text { subjects }\end{array}$ & Type of test & Definition of results & $\begin{array}{l}\text { Allergen molecules tested and } \\
\text { percentage of positive subjects } \\
\text { for each tested allergen }\end{array}$ & Reference \\
\hline & & & & & $\begin{array}{l}(n=17) \text {, Cor a } 8: 80 \% \text { of hazelnut } \\
\text { allergic patients }(n=15) .\end{array}$ & \\
\hline \multirow[t]{2}{*}{$\begin{array}{l}\text { Northern China, } \\
\text { Tangshan }\end{array}$} & Dwa & $\begin{array}{l}203 \text { allergic } \\
\text { patients, sera } \\
\text { collected between }\end{array}$ & $\begin{array}{l}\text { Allergen } \\
\text { component } \\
\text { based }\end{array}$ & $\begin{array}{l}\geq 0.35 \mathrm{IU} / \mathrm{mL} \text { were } \\
\text { defined as slgE } \\
\text { positive }\end{array}$ & $\begin{array}{l}\text { Allergen extracts and allergens } \\
\text { tested: Birch pollen extract, Bet v } \\
\text { 1, Mal d 1, Gly m } 4\end{array}$ & Hao et al. (60) \\
\hline & $\begin{array}{l}\text { Continental, dry winter, } \\
\text { hot summer }\end{array}$ & $\begin{array}{l}\text { February and July } \\
2014\end{array}$ & $\begin{array}{l}\text { serology, } \\
\text { quantitative, } \\
\text { ADVIA Centaur } \\
\text { and } \\
\text { ImmunoCap }\end{array}$ & & $\begin{array}{l}\text { Results obtained: Birch pollen } \\
\text { positive sera: } 16.7 \%(n=34) \text { of } \\
\text { which } 82.4 \% \text { were Bet } \vee 1 \\
\text { positive. } 96.4 \% \text { and } 78.6 \% \text { of Bet } \\
\vee 1 \text {-positive samples were positive } \\
\text { for Mal d } 1 \text { and Gly m } 4 \text {, } \\
\text { respectively. }\end{array}$ & \\
\hline \multirow[t]{2}{*}{ Beijing, China } & Dwa & $\begin{array}{l}83 \text { pollen food } \\
\text { allergic patients } \\
\text { (PFS) and } 46 \text { only } \\
\text { pollen allergic } \\
\text { patients (PS) }\end{array}$ & $\begin{array}{l}\text { Allergen- } \\
\text { component- } \\
\text { based } \\
\text { serology, } \\
\text { quantitative, } \\
\text { ImmunoCap }\end{array}$ & $\begin{array}{l}\geq 0.35 \mathrm{IU} / \mathrm{mL} \text { were } \\
\text { defined as slgE } \\
\text { positive }\end{array}$ & $\begin{array}{l}\text { Pollen allergen sources positive in } \\
\text { more than } 50 \% \text { of patients: White } \\
\text { ash, poplar,birch, Juniper, elm, } \\
\text { phoenix tree, mugwort, Humulus } \\
\text { japonicas, willow, ragweed, } \\
\text { goosefoot, Cirsium jaonicum, } \\
\text { Kochia scoparia, Bermuda grass, } \\
\text { timothy grass. Allergens tested } \\
\text { and with results: Bet v 1, Art v 3, } \\
\text { Gly m 4, Pru p 1, Pru p } 3 \text {. }\end{array}$ & Ma et al. (61) \\
\hline & $\begin{array}{l}\text { Continental, dry winter, } \\
\text { hot summer }\end{array}$ & & & & $\begin{array}{l}\text { Results: Bet v 1: PFS: } 37.3 \% \text {; PS: } \\
\text { 19.6\%) Art v 3: PFS: } 62.7 \% \text {; PS: } \\
\text { 34.8\%, Gly m 4: PFS: } 28.9 \% \text {; PS: } \\
\text { 10.9\%, Pru p 1: PFS: } 31.3 \% \text {; PS: } \\
\text { 13.0\%, Pru p 3: PFS: } 57.8 \% \text {; PS: } \\
\text { 34.8\%. }\end{array}$ & \\
\hline Northern China & $\begin{array}{l}\text { Dwa } \\
\text { Continental, dry winter, } \\
\text { hot summer }\end{array}$ & $\begin{array}{l}70 \text { mugwort } \\
\text { allergic patients } 24 \\
\text { allergic to peach } \\
\text { and mugwort } 15 \\
\text { only peach } 31 \text { only } \\
\text { mugwort }\end{array}$ & $\begin{array}{l}\text { Allergen- } \\
\text { component- } \\
\text { based } \\
\text { serology, } \\
\text { quantitative, } \\
\text { ImmunoCap }\end{array}$ & $\begin{array}{l}\geq 0.35 \mathrm{IU} / \mathrm{mL} \text { were } \\
\text { defined as slgE } \\
\text { positive }\end{array}$ & $\begin{array}{l}\text { Allergens tested: rPru p 1, rPru p } \\
\text { 3, rPru p 4, nArt v 1, nArt v } 3 \\
\text { Results: Larger part of mugwort- } \\
\text { peach allergic patients had higher } \\
\text { IgE to Art v } 3 \text { and lower to Pru p } \\
\text { 3. Few had only Pru p 3-specific } \\
\text { lgE. }\end{array}$ & Gao et al. (62) \\
\hline $\begin{array}{l}\text { Guangzhou city, } \\
\text { China }\end{array}$ & $\begin{array}{l}\text { Cfb } \\
\text { Temperate, no dry } \\
\text { season, Warm summer }\end{array}$ & $\begin{array}{l}18 \text { patients with } \\
\text { bronchopulmonary } \\
\text { aspergillosis } \\
\text { (ABPA) and } 54 \\
\text { Aspergillus- } \\
\text { sensitized asthma } \\
\text { patients (Af) }\end{array}$ & $\begin{array}{l}\text { Allergen- } \\
\text { component- } \\
\text { based } \\
\text { serology, } \\
\text { quantitative, } \\
\text { ImmunoCap }\end{array}$ & $\begin{array}{l}\geq 0.35 \mathrm{IU} / \mathrm{mL} \text { were } \\
\text { defined as slgE } \\
\text { positive }\end{array}$ & $\begin{array}{l}\text { Allergens tested: Asp f 1, Asp f 2, } \\
\text { Asp f 3, Asp f 4, Asp f } 6 \\
\text { Results (ABPA, Af): Asp f 1: } \\
88.89 \% \text { vs. } 59.26 \% \text {, Asp f 2: } \\
66.67 \% \text { vs. } 33.33 \% \text {, Asp f 3: } \\
\text { approx. } 66 \% \text { vs. } 50 \% \text {, Asp f 4: } \\
61.11 \% \text { vs. } 33.33 \% \text {, Asp f 6: } \\
66.67 \% \text { vs. } 14.81 \% .\end{array}$ & Luo et al. (63) \\
\hline
\end{tabular}

China, especially in the northern and central regions. In this context it should be mentioned that IgE sensitization to Art v 3, the LTP from mugwort seemed to be also responsible for plantderived food allergy due to IgE cross-reactivity with the LTP from peach, Pru p 3 (62). In addition, IgE sensitization to Humulus lupulus and profilin thereof seems to be important in China (68).

A comprehensive study performed with recombinant Aspergillus fumigatus allergens confirmed the importance of using these molecules for diagnosis of bronchopulmonary aspergillosis and Aspergillus-related asthma (63). Furthermore, similar IgE recognition profiles for milk and egg allergen molecules were reported in China $(56,57)$ as compared to milk- and egg-sensitized populations from other countries $(69,70)$.

\section{OPEN QUESTIONS WHICH NEED TO BE ADDRESSED BY MOLECULAR DIAGNOSIS}

It is well established that the identification of the genuinesensitizing allergen sources with allergen extracts is hampered by the presence of cross-reactive allergens in different allergen sources (41). Patients exhibiting IgE reactivity to such crossreactive allergens may show allergic symptoms and IgE reactivity to different, often unrelated allergen sources containing such cross-reactive allergens. Studies performed 30 years ago have shown that structural and/or sequence similarity among crossreactive allergens is the basis for IgE cross-reactivity $(71,72)$ Profilins which are ubiquitous actin-binding proteins occurring in eukaryotic organisms were identified as cross-reactive 
allergens especially in pollen of plants and plant-derived food $(72,73)$. Likewise, lipid transfer proteins have been identified as allergens in plant-derived food and also pollen but due to more limited sequence similarity, IgE cross-reactivity is less pronounced $(74,75)$. Calcium-binding proteins containing different numbers of calcium-binding sites have been identified in pollen of unrelated plants as highly cross-reactive allergens (76-78). While the aforementioned cross-reactive plant allergens show allergenic activity and are thus responsible for clinical symptoms, carbohydrate-containing determinants (CCDs) show extensive IgE cross-reactivity but little or no allergenic activity $(79,80)$. CCDs occur in many different unrelated allergen sources (e.g., plants, insects, venoms, house dust mites, molds etc.) as cross-reactive IgE epitopes. Accordingly, CCD-reactive allergic patients may show IgE cross-reactivity to these unrelated allergen sources and be falsely considered to be polysensitized (20). The studies carried out in China with allergen extracts indicate sensitization to pollen from trees, weeds, grasses, and other plants but diagnosis based on allergen extracts can be confounded by the presences of cross-reactive allergens such as profilin, calcium-binding allergens, LTPs and CCDs in pollen from different plants (Figure 5). Only molecular diagnosis will allow to clarify if a patient is co- or cross-sensitized and help identifying the most important allergen sources.

Allergic sensitization to animal dander allergens can also be confounded by the presence of cross-reactive allergens in different animals. For example, albumin has been identified as a cross-reactive allergen in many animals and cow's milk (81, 82). IgE cross-reactivity between Fel $d 7$ and Can $\mathrm{f} 1$ may confound the differential diagnosis of cat and dog allergy (83) and Fel d 4-related allergens may occur as cross-reactive allergen in different animals (84). Accordingly, molecular diagnosis will be necessary to determine the correct frequency of allergic sensitization to different animals and to identify the culprit allergen source responsible for sensitization.

Likewise, diagnosis of allergic sensitization to HDMs, tropical mites (e.g., Blomia tropicalis), cockroach, crab, shrimp, and other seafood belonging to the invertebrates can be obscured by $\operatorname{IgE}$ reactivity to cross-reactive allergens such as tropomyosin and arginine kinase whereas glutathione $S$ transferase may serve as source-specific marker allergen due to low cross-reactivity of GST cockroach, dust mites and helminths (Figure 6) (85-90). In this context we noted that IgE sensitization and skin sensitivity to shrimp and crab were especially common in areas of China where HDM sensitization rates were high (Table 2).

Molecular diagnosis has also become of high importance in the diagnosis of food allergy (47). IgE recognition of class 1 food allergens which usually sensitize via ingestion and represent stable proteins which are poorly degraded in the gastrointestinal tract is usually related with severe and systemic symptoms of food allergy. By contrast, class 2 food allergens are proteins which sensitize via the respiratory tract and with exceptions (e.g., LTPs which can serve also as class 1 food allergens) they are usually easily degraded in the gastrointestinal tract and hence cause mainly mild and not life-threatening symptoms of allergy restricted to the mouth (e.g., oral allergy syndrome) or to chronic allergic inflammation (e.g., atopic dermatitis) in other organs caused by activation of $\mathrm{T}$ cell
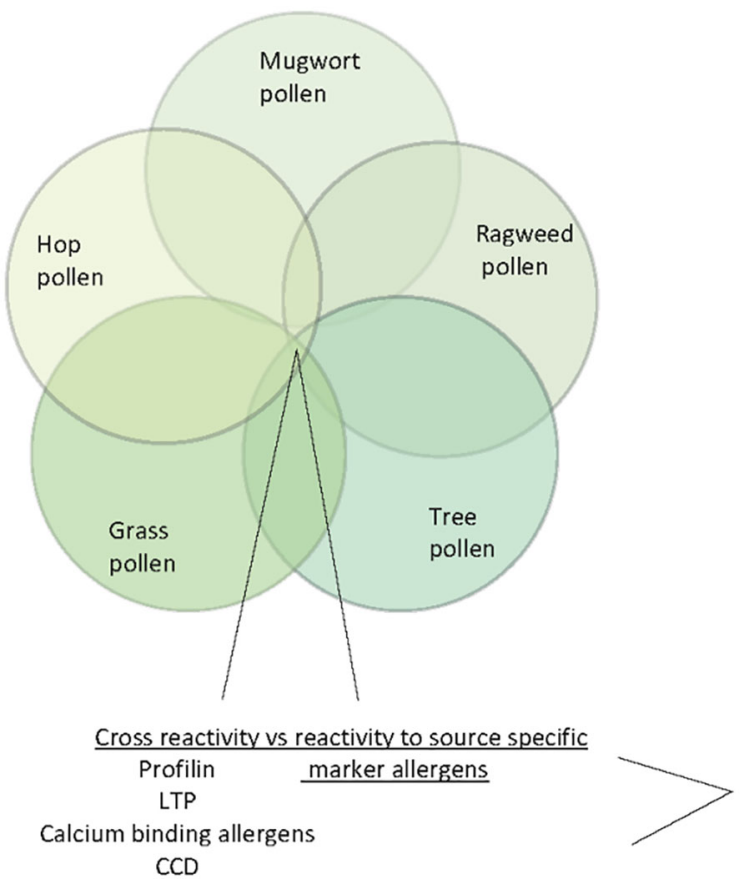

Co- and/or

Cross-sensitisation

FIGURE 5 | Venn diagram of pollen allergen sources (ragweed, mugwort, tree pollen, hop pollen and grass pollen) indicating cross-reactive allergens/lgE-reactive antigens (profilin, LTP, calcium-binding allergens and CCDs). 


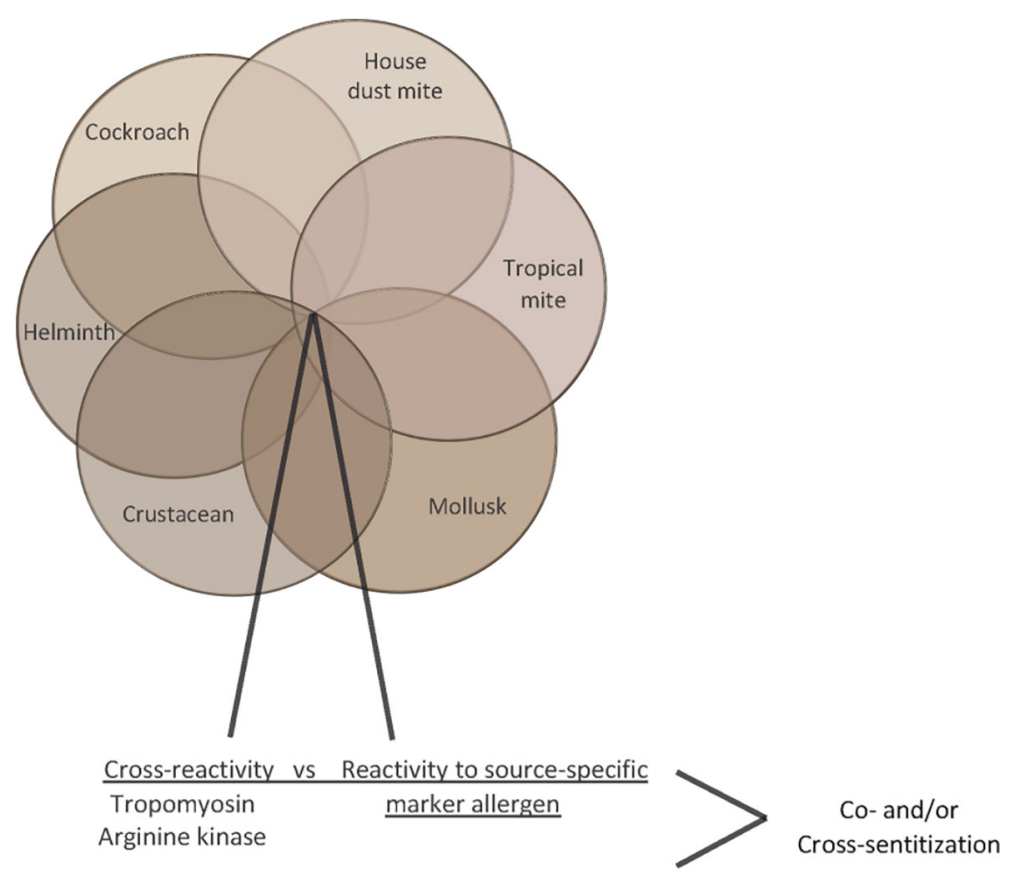

FIGURE 6 | Venn diagram of invertebrate allergen sources (house dust mites, tropical mites, cockroach, crab, shrimp) indicating cross-reactive allergens (tropomyosin, arginine kinase).

epitope containing peptides without anaphylactic activity. Figure 7 provides an overview of some food allergen sources containing class 1 food allergens and mentions food allergen molecules which can serve as class 2 (e.g., PR10 allergens, profilin, albumin) and in certain cases also as class 2 and/or as class 1 food allergens (e.g., LTP, tropomyosin, arginine kinase). The fact, that food allergen sources can contain class 1 and class 2 allergens at the same time emphasizes the importance of molecular diagnosis for the prediction of the likelihood of a patient to experience no, mild, or severe forms of food allergy symptoms. In addition, it is important to understand if a respiratory or food allergen source was responsible for sensitization. Several epidemiological research studies on allergen molecules have been performed in China but the detection of molecular IgE sensitizations responsible for clinically meaningful cross-reactivity will need confirmation by case history, IgE-inhibition studies, and provocation testing.

\section{TOWARDS A COMPLETE MAP OF THE MOLECULAR IGE SENSITIZATION PROFILE IN CHINA AS A BASIS FOR ALLERGEN-SPECIFIC PREVENTION AND TREATMENT}

The identification of the clinically most relevant allergen molecules is a prerequisite for the rationale establishment of allergen-specific strategies for treatment and prevention.
The unbiased testing of IgE sensitization to a large panel of allergen molecules has become possible with the generation of chips containing micro-arrayed allergen molecules (40). Such chips allow the testing of IgE reactivity to hundreds of purified allergen molecules with only microliter volumes of serum. However, molecular testing needs to be compared with allergen extract based testing and sensitivity and specificity should be determined especially in patients with low IgE sensitization. The MeDALL allergen chip which has been created within an EUfunded research program (Mechanisms of the Development of Allergy MeDALL) (1) is an example for such a chip which has been successfully used to determine molecular IgE sensitization profiles in European birth cohorts (13). A similar, but advanced technology (91) could be used to create allergen microarrays for the assessment of IgE sensitization profiles in different regions of China. The advantage of testing a large panel of allergen molecules by a discovery approach instead of testing with a pre-selected limited panel of allergen molecules or allergen extracts is that the multiallergen screening test approach is not biased, precisely identifies the allergen molecules and thus allows to discover yet unanticipated sensitizations. As explained above, it is important to link IgE recognition profiles and allergen-specific IgE antibody levels with clinical symptoms in order to identify clinically relevant sensitizations to particular allergens and/or groups of allergens. In this context it should be mentioned that several studies show that not only specific IgE levels to a particular allergen but also cumulative specific IgE levels to several allergen molecules are associated with types and severity of symptoms and allergic phenotypes $(2,92,93)$. Multiallergen diagnosis seems to 


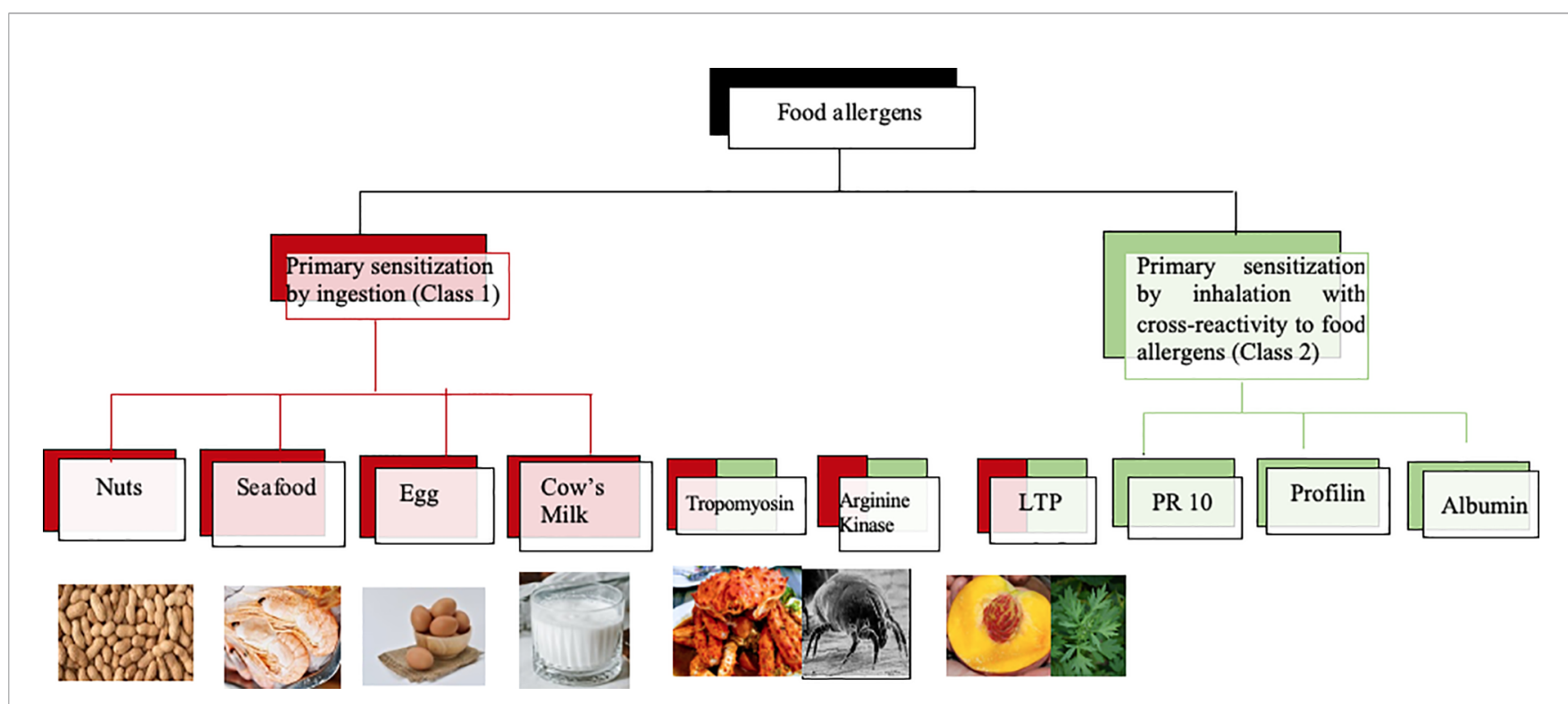

FIGURE 7 | Class 1 and class 2 food allergens/allergen sources with possible relevance for Chinese patients. Class 1 food allergens/allergen sources are indicated in red, class 2 food allergens in green whereas allergens which may behave as class 1 and 2 allergens contain red and green color.

be particularly suitable for linking IgE-sensitization profiles with disease phenotypes. Regarding China, it seems that an approach of testing subjects from different regions of the country will be needed to differentiate the IgE sensitization profiles in the different regions because data available from allergen extractbased testing have already indicated that IgE sensitization profiles will vary between different geographic regions depending on the local exposomes (Tables 2, 3; Figures 3 and 4). We know from birth cohort studies that IgE-reactivity profiles consolidate between 10-16 years of age $(6,7)$ and are then stable in adult patients (94). Accordingly, it is suggested to perform a crosssectional multicenter study involving different regions and to enroll adolescent subjects who were born and raised in the investigated area to appropriately grasp the local sensitization profiles. In a recent study conducted in Moscow, Russia (4), it turned out to be of advantage to investigate not only subjects with allergic symptoms but to also investigate a sex- and age-matched control group of subjects without allergic symptoms. This study design actually allowed to identify subjects with a clinically-silent IgE sensitization which allows to characterize the features of a clinically silent IgE sensitization and to compare it with IgE sensitization profiles of subjects with symptoms. This study design has enabled to identify clinically irrelevant types of allergens (e.g., CCDs), IgE reactivity profiles and/or specific IgE threshold levels associated with symptoms and certain phenotypes of disease. For example, CCDs on Phl p 4 and Cyn d 1 were identified as clinically irrelevant "allergens" $(17,95)$ and IgE threshold levels to major birch pollen allergen, Bet $\mathrm{v} 1$, associated with symptomatic birch pollen allergy and certain phenotypes of birch pollen allergy (i.e., oral allergy syndrome) were found (93). Ideally, subjects for a cross-sectional study should not yet have undergone allergy diagnosis because inclusion of patients from allergy centers focusing on certain forms of allergy (e.g., respiratory allergy, food allergy or skin manifestations) may create unwanted selection bias. Therefore, it is recommended to recruit subjects de novo for a cross-sectional survey by advertisement and to use an established questionnaire such as the ISAAC questionnaire (96), to form equally sized and matched groups of subjects with and without symptoms of allergy (Figure 8). Based on an anticipated frequency of allergy of $30 \%$ and IgE sensitizations of up to $60 \%$ it should be sufficient to analyze approximately 100-200 subjects with and 100-200 subjects without allergy symptoms in each of the centers to obtain an overview of IgE sensitization profiles. A detailed allergy anamnesis according to a procedure which is identical for each of the study centers is recommended for subjects with allergy symptoms to clinically define allergic phenotypes in the group of subjects with allergic symptoms. It may well be that not only IgE sensitization profiles, but also allergic phenotypes may vary in different regions. For example, seafood allergy may be more prominent in regions where seafood is consumed, and seasonal allergy may be more frequent in the regions with heavy pollen exposure.

Serum samples obtained in the different study centers should then be anonymized and analyzed in a blinded manner in a core laboratory to allow unbiased analysis and to minimize or avoid variations regarding the sIgE measurements due to methodological issues caused by different equipment and variation of test batches. Results from the multiallergen testing and clinical parameters can then be pooled in a database and be subjected to further analysis to identify clinically relevant allergens for each region as a basis for rational allergen-specific treatment and preventive strategies (10). In addition, a wealth of additional data may be expected which can be implemented in diagnostic and predictive algorithms useful for precision medicine treatment $(97,98)$. 


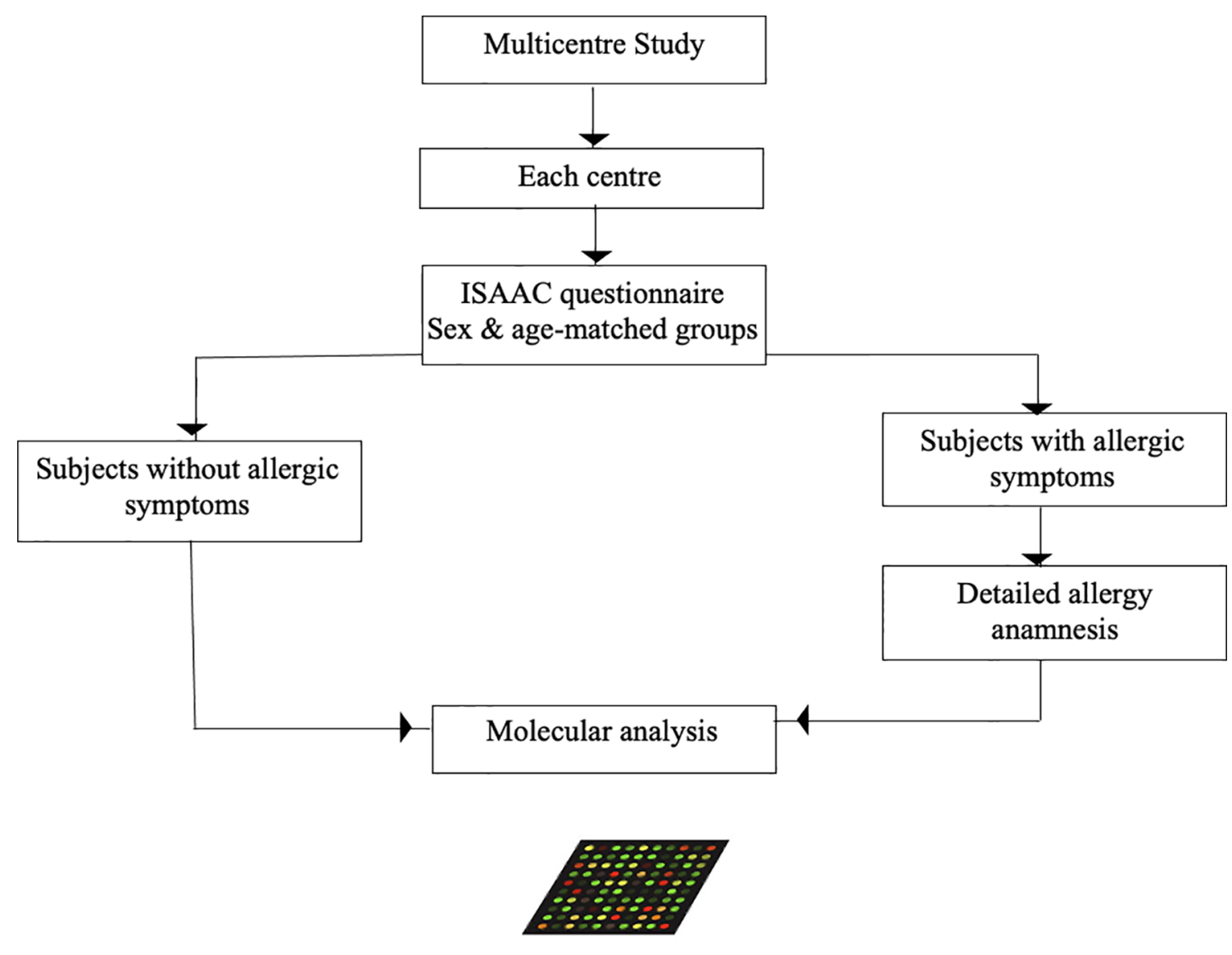

Identification of relevant allergen molecules in different regions of the country

FIGURE 8 | Possible design of a multicenter study to determine the relevant allergen molecules in the different regions of China. Sex- and age matched groups of equal number with or without allergic symptoms according to ISAAC questionnaire are obtained from the regional population of each center. In subjects with allergic symptoms a detailed anamnesis of allergic symptoms is performed. Sera from the subjects with and without allergic symptoms are then analyzed in an anonymized and blinded manner to determine the molecular lgE sensitization profiles in a qualitative (i.e., nature of IgE-positive allergens) and quantitative (i.e., allergen-specific IgE levels) manner to define the relevant allergen molecules in each region of the country.

\section{SUMMARY AND CONCLUSIONS}

China is the country with the world's largest population comprising approximately 1.4 million with an estimated number of at least 400 million allergic patients. Accordingly, the development of affordable allergen-specific diagnosis, treatment and prevention strategies for allergy is a major health priority in this country. The basis for allergen-specific intervention strategies is a detailed knowledge of the allergen sensitization profiles and the identification of the clinically most relevant allergens in the country. Using allergen extracts and recently defined allergen molecules rapid progress has already been made regarding the identification of important allergens in China. These studies have indicated that due to several factors including especially the occurrence of different climates in different regions of the country, heterogeneities regarding $\operatorname{IgE}$ sensitizations due to locally different exposomes exist in China. Due to the existence of cross-reactive allergens in different allergen sources, molecular IgE diagnosis is therefore required for the further deconvolution of $\mathrm{IgE}$ sensitization profiles to identify the clinically most important allergens in different regions of China and to develop allergen-specific forms of treatment and prevention.

\section{AUTHOR CONTRIBUTIONS}

RV and ND's wrote the manuscript. RV, ND's, and MW designed the figures and tables. ND's, MW, MS, ES, and MF-T contributed materials. MF-T, ES, MW, SV, MC, MS, ND's, and 
RV critically read and revised the manuscript. All authors contributed to the article and approved the submitted version.

\section{FUNDING}

Supported by the Danube Allergy Research Cluster funded by the Country of Lower Austria, by the MCCA PhD program of the Austrian Science Fund (FWF), by the Russian Academic Excellence Project 5-100, by a Megagrant of the Government of the Russian Federation, grant No 14.W03.31.0024, by a research grant from Worg Pharmaceuticals, Hangzhou, China and by grant from HVD Life Science, Vienna, Austria. The

\section{REFERENCES}

1. Anto JM, Bousquet J, Akdis M, Auffray C, Keil T, Momas I, et al. Mechanisms of the Development of Allergy (MeDALL): Introducing Novel Concepts in Allergy Phenotypes. J Allergy Clin Immunol (2017) 139(2):388-99. doi: 10.1016/j.jaci.2016.12.940

2. Siroux V, Boudier A, Nadif R, Lupinek C, Valenta R, Bousquet J. Association Between Asthma, Rhinitis, and Conjunctivitis Multimorbidities With Molecular IgE Sensitization in Adults. Allergy (2019) 74(4):824-7. doi: 10.1111/all.13676

3. Westman M, Asarnoj A, Hamsten C, Wickman M, van Hage M. Windows of Opportunity for Tolerance Induction for Allergy by Studying the Evolution of Allergic Sensitization in Birth Cohorts. Immunology (2017) 30:61-6. doi: 10.1016/j.smim.2017.07.005

4. Elisyutina O, Lupinek C, Fedenko E, Litovkina A, Smolnikov E, Ilina N, et al. IgE-Reactivity Profiles to Allergen Molecules in Russian Children With and Without Symptoms of Allergy Revealed by Micro-Array Analysis. Pediatr Allergy Immunol (2021) 32(2):251-63. doi: 10.1111/ pai. 13354

5. Westman M, Lupinek C, Bousquet J, Andersson N, Pahr S, Baar A, et al. Early Childhood IgE Reactivity to Pathogenesis-Related Class 10 Proteins Predicts Allergic Rhinitis in Adolescence. J Allergy Clin Immunol (2015) 135(5):1199206.e1-11. doi: 10.1016/j.jaci.2014.10.042

6. Posa D, Perna S, Resch Y, Lupinek C, Panetta V, Hofmaier S, et al. Evolution and Predictive Value of IgE Responses Toward a Comprehensive Panel of House Dust Mite Allergens During the First 2 Decades of Life. J Allergy Clin Immunol (2017) 139(2):541-9.e8. doi: 10.1016/j.jaci.2016.08.014

7. Wickman M, Lupinek C, Andersson N, Belgrave D, Asarnoj A, Benet M, et al. Detection of IgE Reactivity to a Handful of Allergen Molecules in Early Childhood Predicts Respiratory Allergy in Adolescence. EBioMedicine (2017) 26:91-9. doi: 10.1016/j.ebiom.2017.11.00

8. Hamelmann E, Herz U, Holt P, Host A, Lauener RP, Matricardi PM, et al. New Visions for Basic Research and Primary Prevention of Pediatric Allergy: An iPAC Summary and Future Trends. Pediatr Allergy Immunol (2008) 19 (Suppl 19):4-16. doi: 10.1111/j.1399-3038.2008.00763.x

9. Fisher HR, Du Toit G, Bahnson HT, Lack G. The Challenges of Preventing Food Allergy: Lessons Learned From LEAP and EAT. Ann Allergy Asthma Immunol (2018) 121(3):313-9. doi: 10.1016/j.anai.2018.06.008

10. Dorofeeva Y, Shilovskiy I, Tulaeva I, Focke-Tejkl M, Flicker S, Kudlay D, et al. Past, Present, and Future of Allergen Immunotherapy Vaccines. Allergy (2021) 76(1):131-49. doi: 10.1111/all.14300

11. Tulaeva I, Kratzer B, Campana R, Curin M, van Hage M, Karsonova A, et al. Preventive Allergen-Specific Vaccination Against Allergy: Mission Possible? Front Immunol (2020) 11:1368. doi: 10.3389/fimmu.2020.01368

12. Dramburg S, Marchante Fernández M, Potapova E, Matricardi PM. The Potential of Clinical Decision Support Systems for Prevention, Diagnosis, and Monitoring of Allergic Diseases. Front Immunol (2020) 11:2116. doi: 10.3389/ fimmu.2020.02116 funders were not involved in the study design, collection, analysis, interpretation of data, the writing of this article or the decision to submit it for publication.

\section{ACKNOWLEDGMENTS}

The authors acknowledge the support of the Medical University of Vienna, Austria for the research infrastructure. The authors thank Dr. Rainer Henning, Worg Pharmaceuticals, Hangzhou, People's Republic of China and Alexander Hill, HVD, Moscow, Russia for stimulating discussions and critical reading of the manuscript.

13. Lupinek C, Wollmann E, Baar A, Banerjee S, Breiteneder H, Broecker BM, et al. Advances in Allergen-Microarray Technology for Diagnosis and Monitoring of Allergy: The MeDALL Allergen-Chip. Methods (2014) 66 (1):106-19. doi: 10.1016/j.ymeth.2013.10.008

14. Movérare R, Westritschnig K, Svensson M, Hayek B, Bende M, Pauli G, et al. Different IgE Reactivity Profiles in Birch Pollen-Sensitive Patients From Six European Populations Revealed by Recombinant Allergens: An Imprint of Local Sensitization. Int Arch Allergy Immunol (2002) 128(4):325-35. doi: $10.1159 / 000063855$

15. Movérare R, Larsson H, Carlsson R, Holmquist I. Mugwort-Sensitized Individuals From North Europe, South Europe and North America Show Different IgE Reactivity Patterns. Int Arch Allergy Immunol (2011) 154 (2):164-72. doi: 10.1159/000320231

16. Siroux V, Lupinek C, Resch Y, Curin M, Just J, Keil T, et al. Specific IgE and IgG Measured by the MeDALL Allergen-Chip Depend on Allergen and Route of Exposure: The EGEA Study. J Allergy Clin Immunol (2017) 139(2):64354.e6. doi: 10.1016/j.jaci.2016.05.023

17. Cabauatan CR, Lupinek C, Scheiblhofer S, Weiss R, Focke-Tejkl M, Bhalla PL, et al. Allergen Microarray Detects High Prevalence of Asymptomatic IgE Sensitizations to Tropical Pollen-Derived Carbohydrates. J Allergy Clin Immunol (2014) 133(3):910-4.e5. doi: 10.1016/j.jaci.2013.10.004

18. Mari A. IgE to Cross-Reactive Carbohydrate Determinants: Analysis of the Distribution and Appraisal of the In Vivo and In Vitro Reactivity. Int Arch Allergy Immunol (2002) 129(4):286-95. doi: 10.1159/00006759

19. Westritschnig K, Horak F, Swoboda I, Balic N, Spitzauer S, Kundi M, et al. Different Allergenic Activity of Grass Pollen Allergens Revealed by Skin Testing. Eur J Clin Invest (2008) 38(4):260-7. doi: 10.1111/j.13652362.2008.01938.x

20. Gattinger P, Mittermann I, Lupinek C, Hofer G, Keller W, Bidovec Stojkovic U, et al. Recombinant Glycoproteins Resembling Carbohydrate-Specific IgE Epitopes From Plants, Venoms and Mites. EBioMedicine (2019) 39:33-43. doi: 10.1016/j.ebiom.2018.12.002

21. Garib V, Wollmann E, Djambekova G, Lemell P, Kmenta M, Berger U, et al. Possible Effect of Landscape Design on IgE Recognition Profiles of Two Generations Revealed With Micro-Arrayed Allergens. Allergy (2017) 72 (10):1579-82. doi: 10.1111/all.13169

22. Geiger R. Klassifikation Der Klimate Nach W. Köppen” Classification of Climates After W. Köppen. In: Landolt-Börnstein - Zahlenwerte Und Funktionen Aus Physik, Chemie, Astronomie, Geophysik Und Technik, Alte Serie, vol. 3. Berlin: Springer (1954). p. 603-7.

23. Geiger R. Überarbeitete Neuausgabe Von Geiger, R.: Köppen-Geiger/Klima Der Erde. (Wandkarte 1:16 Mill.) - Klett-Perthes, Gotha. (1961).

24. Zeng G, Luo W, Wu Z, Li L, Zheng P, Huang H, et al. A Cross-Sectional Observational Study on Allergen-Specific IgE Positivity in a Southeast Coastal Versus a Southwest Inland Region of China. Sci Rep (2017) 7(1):9593. doi: 10.1038/s41598-017-10109-3

25. Liu X, Zheng P, Zheng SG, Zhai Y, Zhao X, Chen Y, et al. Co-Sensitization and Cross-Reactivity of Blomia Tropicalis With Two Dermatophagoides Species 
in Guangzhou, China. J Clin Lab Anal (2019) 33(9):e22981. doi: 10.1002/ jcla.22981

26. Sun BQ, Lai XX, Gjesing B, Spangfort MD, Zhong NS. Prevalence of Sensitivity to Cockroach Allergens and IgE Cross-Reactivity Between Cockroach and House Dust Mite Allergens in Chinese Patients With Allergic Rhinitis and Asthma. Chin Med J (Engl) (2010) 123(24):3540-4. doi: 10.3760/cma.j.issn.0366-6999.2010.24.007

27. Luo W, Hu H, Tang W, Zou X, Huang H, Huang Z, et al. Allergen Sensitization Pattern of Allergic Adults and Children in Southern China: A Survey Based on Real Life Data. Allergy Asthma Clin Immunol (2019) 15:42. doi: 10.1186/s13223-019-0357-y

28. Luo W, Chen H, Wu Z, Hu H, Tang W, Chen H, et al. A New Trend in Sensitization to Cockroach Allergen: A Cross-Sectional Study of Indoor Allergens and Food Allergens in the Inland Region of Southwest China. Asian Pac J Allergy Immunol (2020). doi: 10.12932/AP-281019-0678

29. Huang H, Luo W, Wei N, Liang X, Zheng P, Hu H, et al. Distribution Characteristics of Cow's Milk-Sige Components in Children With Respiratory Allergic Diseases in Southern China. BMC Pediatr (2020) 20(1):88. doi: 10.1186/s12887-020-1971-Z

30. Yan YR, Xu YH, Zheng Q, Guo YS. The Prevalence and Sex Difference of Allergen Sensitization Among Adult Patients With Allergic Diseases in Shanghai, China. Asian Pac J Allergy Immunol (2019) 37(3):147-53. doi: 10.12932/AP-150118-0241

31. Zeng D, Li W, Zhou J, Wen X, Chen S, Xie X, et al. Analysis of the Immunoglobin E Molecular Sensitization Profile in Children With Allergic Asthma and Predictive Factors for the Efficacy of Allergy Immunotherapy. Ann Transl Med (2020) 8(21):1459. doi: 10.21037/atm-20-7314

32. Zeng GQ, Luo JY, Huang HM, Zheng PY, Luo WT, Wei NL, et al. Food Allergy and Related Risk Factors in 2540 Preschool Children: An Epidemiological Survey in Guangdong Province, Southern China. World J Pediatr (2015) 11(3):219-25. doi: 10.1007/s12519-015-0030-6

33. Mao S, Wu L, Shi W. Prevalence and Distribution Patterns of Allergens Among Children With Asthma and Asthma-Like Symptoms in Shanghai, China. Respir Res (2020) 21(1):57. doi: 10.1186/s12931-020-1318-1

34. Lin H, Lin R, Li N. Sensitization Rates for Various Allergens in Children With Allergic Rhinitis in Qingdao, China. Int J Environ Res Public Health (2015) 12 (9):10984-94. doi: 10.3390/ijerph120910984

35. Luo W, Wang D, Zhang T, Zheng P, Leng D, Li L, et al. Prevalence Patterns of Allergen Sensitization by Region, Gender, Age, and Season Among Patients With Allergic Symptoms in Mainland China: A Four-Year Multicenter Study. Allergy (2021) 76(2):589-93. doi: 10.1111/all.14597

36. Chen CJ, Liu YH, Lin TY, Jan RH. Allergen Detection and Analysis in Eastern Taiwan Area. Tzu Chi Med J (2020) 33(2):165-8. doi: 10.4103/tcmj.tcmj_72_20

37. Kazemi-Shirazi L, Niederberger V, Linhart B, Lidholm J, Kraft D, Valenta R. Recombinant Marker Allergens: Diagnostic Gatekeepers for the Treatment of Allergy. Int Arch Allergy Immunol (2002) 127(4):259-68. doi: 10.1159/ 000057742

38. Valenta R. Biochemistry of Allergens, Recombinant Allergens. In: AB Kay, A Kaplan, J Bousquet, P Holt, editors. Allergy and Allergic Diseases, 2nd Edition. New Jersey, United States: Blackwell PublishingBlackwell publishing (2009). p. 895-912. Available at: http://www.eu.wiley/com/WileyCDA/WileyTitle/ productCd1405157208.html.

39. Valenta R, Duchene M, Vrtala S, Birkner T, Ebner C, Hirschwehr R, et al. Recombinant Allergens for Immunoblot Diagnosis of Tree-Pollen Allergy. J Allergy Clin Immunol (1991) 88(6):889-94. doi: 10.1016/0091-6749(91)90245-j

40. Hiller R, Laffer S, Harwanegg C, Huber M, Schmidt WM, Twardosz A, et al. Microarrayed Allergen Molecules: Diagnostic Gatekeepers for Allergy Treatment. FASEB J (2002) 16(3):414-6. doi: 10.1096/fj.01-0711fje

41. Matricardi PM, Kleine-Tebbe J, Hoffmann HJ, Valenta R, Hilger C, Hofmaier S, et al. EAACI Molecular Allergology User's Guide. Pediatr Allergy Immunol (2016) 27 Suppl 23:1-250. doi: 10.1111/pai.12563

42. Burbach GJ, Heinzerling LM, Edenharter G, Bachert C, Bindslev-Jensen C, Bonini S, et al. GA(2)LEN Skin Test Study II: Clinical Relevance of Inhalant Allergen Sensitizations in Europe. Allergy (2009) 64(10):1507-15. doi: 10.1111/j.1398-9995.2009.02089.x

43. Caraballo L, Valenta R, Acevedo N, Zakzuk J. Are the Terms Major and Minor Allergens Useful for Precision Allergology? Front Immunol (2021) 12:651500. doi: $10.3389 /$ fimmu.2021.651500
44. Caraballo L, Valenta R, Puerta L, Pomés A, Zakzuk J, Fernandez-Caldas E, et al. The Allergenic Activity and Clinical Impact of Individual IgE-Antibody Binding Molecules From Indoor Allergen Sources. World Allergy Organ J (2020) 13(5):100118. doi: 10.1016/j.waojou.2020.100118

45. Gieras A, Linhart B, Roux KH, Dutta M, Khodoun M, Zafred D, et al. IgE Epitope Proximity Determines Immune Complex Shape and Effector Cell Activation Capacity. J Allergy Clin Immunol (2016) 137(5):1557-65. doi: 10.1016/j.jaci.2015.08.055

46. Valenta R, Karaulov A, Niederberger V, Gattinger P, van Hage M, Flicker S, et al. Molecular Aspects of Allergens and Allergy. Adv Immunol (2018) 138:195-256. doi: 10.1016/bs.ai.2018.03.002

47. Valenta R, Hochwallner H, Linhart B, Pahr S. Food Allergies: The Basics. Gastroenterology (2015) 148(6):1120-31.e4. doi: 10.1053/j.gastro.2015.02.006

48. Valenta R, Karaulov A, Niederberger V, Zhernov Y, Elisyutina O, Campana R, et al. Allergen Extracts for In Vivo Diagnosis and Treatment of Allergy: Is There a Future? J Allergy Clin Immunol Pract (2018) 6(6):1845-55.e2. doi: 10.1016/j.jaip.2018.08.032

49. Bousquet J, Gern JE, Martinez FD, Anto JM, Johnson CC, Holt PG, et al. Birth Cohorts in Asthma and Allergic Diseases: Report of a NIAID/NHLBI/ MeDALL Joint Workshop. J Allergy Clin Immunol (2014) 133(6):1535-46. doi: 10.1016/j.jaci.2014.01.018

50. Huang Z, Zou X, Chen H, Liao C, Hu H, Luo W, et al. Identifying Potential Co-Sensitization and Cross-Reactivity Patterns Based on ComponentResolved Diagnosis. Int Arch Allergy Immunol (2020) 181(2):81-93. doi: $10.1159 / 000504320$

51. Hu H, Luo W, Wu Z, Cai C, Huang H, Sun B. A Pilot Study on the AllergenSpecific IgE to Molecular Components on Polysensitized Mite Allergic Asthmatic Patients in Guangzhou, China. Mol Immunol (2019) 105:38-45. doi: 10.1016/j.molimm.2018.11.004

52. Luo W, Huang H, Zheng P, Wei N, Luo J, Sun B, et al. Major Grass Pollen Allergens and Components Detected in a Southern Chinese Cohort of Patients With Allergic Rhinitis and/or Asthma. Mol Immunol (2016) 78:105-12. doi: 10.1016/j.molimm.2016.08.013

53. Gao Z, Fu WY, Sun Y, Gao B, Wang HY, Liu M, et al. Artemisia Pollen Allergy in China: Component-Resolved Diagnosis Reveals Allergic Asthma Patients Have Significant Multiple Allergen Sensitization. Allergy (2018) 74(2):284-93. doi: 10.1111/all.13597

54. Liao C, Liang C, Hu H, Luo W, Wu G, Huang Z, et al. Major Pollen Allergen Components and CCD Detection in Bermuda Grass Sensitized Patients in Guangzhou, China. J Asthma Allergy (2020) 13:615-23. doi: 10.2147/ JAA.S277704

55. Zeng G, Luo W, Zheng P, Wie N, Huang H, Sun B, et al. Component-Resolved Diagnostic Study of Dermatophagoides Pteronyssinus Major Allergen Molecules in a Southern Chinese Cohort. J Investig Allergol Clin Immunol (2015) 25(5):343-51. doi: 10.1016/j.jaci.2014.12.1734

56. Li J, Zhang J, Qiong C, She T, Bian Y, Lin S, et al. Component Resolved Diagnostic Study of Cow's Milk Allergy in Infants and Young Children in Northern China. Int Immunopharmacol (2018) 61:126-31. doi: 10.1016/ j.intimp.2018.05.027

57. Zhang J, Shen Y, Li J, Li H, Si P. Component-Resolved Diagnostic Study of Egg Allergy in Northern Chinese Children. BioMed Res Int (2020) 2020 (3831087):9. doi: 10.1155/2020/3831087

58. Li JD, Du ZR, Liu J, Xu YY, Wang RQ, Yin J. Characteristics of Pollen-Related Food Allergy Based on Individual Pollen Allergy Profiles in the Chinese Population. World Allergy Organ J (2020) 13(5):100120. doi: 10.1016/ j.waojou.2020.100120

59. Deng S, Yin J. Clinical Utility of Basophil Activation Test in Diagnosis and Predicting Severity of Mugwort Pollen-Related Peach Allergy. World Allergy Organ J (2019) 12(6):100043. doi: 10.1016/j.waojou.2019.100043

60. Hao GD, Zheng YW, Wang ZX, Kong XA, Song ZJ, Lai XX, et al. High Correlation of Specific IgE Sensitization Between Birch Pollen, Soy and Apple Allergens Indicates Pollen-Food Allergy Syndrome Among Birch Pollen Allergic Patients in Northern China. J Zhejiang Univ Sci B (2016) 17 (5):399-404. doi: 10.1631/jzus.B1500279

61. Ma S, Wang R, Nie L, Yin J. Pollen Food Allergy Syndrome in China. Food Agric Immunol (2018) 29(1):281-93. doi: 10.1080/09540105.2017.1372372

62. Gao ZS, Yang ZW, Wu SD, Wang HY, Liu ML, Mao WL, et al. Peach Allergy in China: A Dominant Role for Mugwort Pollen Lipid Transfer Protein as a 
Primary Sensitizer. J Allergy Clin Immunol (2013) 131(1):224-6.e1-3. doi: 10.1016/j.jaci.2012.07.015

63. Luo W, Hu H, Wu Z, Wei N, Huang H, Zheng P, et al. Molecular Allergen Sensitization of Aspergillus Fumigatus Between Allergic Bronchopulmonary Aspergillosis and A fumigatus-Sensitized Asthma in Guangzhou, Southern China. J Clin Lab Anal (2020) 34(10):e23448. doi: 10.1002/jcla.23448

64. Kidon MI, Chiang WC, Liew WK, Ong TC, Tiong YS, Wong KN, et al. Mite Component-Specific IgE Repertoire and Phenotypes of Allergic Disease in Childhood: The Tropical Perspective. Pediatr Allergy Immunol (2011) 22 (2):202-10. doi: 10.1111/j.1399-3038.2010.01094

65. Cheong N, Ramos JD, Tang CY, Chng HH, Yao R, Liang Z, et al. Mite Amylase From Blomia Tropicalis (Blo T 4): Differential Allergenicity Linked to Geographical Regions. Int Arch Allergy Immunol (2009) 149(1):25-32. doi: $10.1159 / 000176303$

66. Walton SF, Slender A, Pizutto S, Mounsey KE, Oprescu F, Thomas WR, et al. Analysis of IgE Binding Patterns to House Dust Mite Allergens in ScabiesEndemic Communities: Insights for Both Diseases. Clin Exp Allergy (2016) 46 (3):508. doi: 10.1111/cea.12713

67. Hales BJ, Laing IA, Pearce LJ, Hazell LA, Mills KL, Chua KY, et al. Distinctive Immunoglobulin E Anti-House Dust Allergen-Binding Specificities in a Tropical Australian Aboriginal Community. Clin Exp Allergy (2007) 37 (9):1357-63. doi: 10.1111/j.1365-2222.2007.02786.x

68. Hong Q, Zhou S, Zhao H, Peng J, Li Y, Shang Y, et al. Allergenicity of Recombinant Humulus Japonicus Pollen Allergen 1 After Combined Exposure to Ozone and Nitrogen Dioxide. Environ Pollut (2018) 234:70715. doi: 10.1016/j.envpol.2017.11.078

69. Hochwallner H, Schulmeister U, Swoboda I, Balic N, Geller B, Nystrand M, et al. Microarray and Allergenic Activity Assessment of Milk Allergens. Clin Exp Allergy (2010) 40(12):1809-18. doi: 10.1111/j.1365-2222.2010.03602.x

70. Dhanapala P, Doran T, Tang ML, Suphioglu C. Production and Immunological Analysis of IgE Reactive Recombinant Egg White Allergens Expressed in Escherichia Coli. Mol Immunol (2015) 65(1):104-12. doi: 10.1016/j.molimm.2015.01.006

71. Valenta R, Duchêne M, Pettenburger K, Sillaber C, Valent P, Bettelheim P, et al. Identification of Profilin as a Novel Pollen Allergen; IgE Autoreactivity in Sensitized Individuals. Science (1991) 253(5019):557-60. doi: 10.1126/ science. 1857985

72. Valenta R, Duchene M, Ebner C, Valent P, Sillaber C, Deviller P, et al. Profilins Constitute a Novel Family of Functional Plant Pan-Allergens. J Exp Med (1992) 175(2):377-85. doi: 10.1084/jem.175.2.377

73. Valenta R, Ferreira F, Grote M, Swoboda I, Vrtala S, Duchêne M, et al. Identification of Profilin as an Actin-Binding Protein in Higher Plants. J Biol Chem (1993) 268(30):22777-81. doi: 10.1016/S0021-9258(18)41594-3

74. Pastorello EA, Farioli L, Pravettoni V, Ortolani C, Ispano M, Monza M, et al. The Major Allergen of Peach (Prunus Persica) Is a Lipid Transfer Protein. J Allergy Clin Immunol (1999) 103(3 Pt 1):520-6. doi: 10.1016/s0091-6749(99) 70480-x

75. Pastorello EA, Pravettoni V, Farioli L, Rivolta F, Conti A, Ispano M, et al. Hypersensitivity to Mugwort (Artemisia Vulgaris) in Patients With Peach Allergy Is Due to a Common Lipid Transfer Protein Allergen and Is Often Without Clinical Expression. J Allergy Clin Immunol (2002) 110(2):310-7. doi: $10.1067 /$ mai.2002.125830

76. Seiberler S, Scheiner O, Kraft D, Lonsdale D, Valenta R. Characterization of a Birch Pollen Allergen, Bet V III, Representing a Novel Class of Ca2+ Binding Proteins: Specific Expression in Mature Pollen and Dependence of Patients' IgE Binding on Protein-Bound Ca2+. EMBO J (1994) 13(15):3481-6. doi: 10.1002/j.1460-2075.1994.tb06654.x

77. Twardosz A, Hayek B, Seiberler S, Vangelista L, Elfman L, Grönlund H, et al. Molecular Characterization, Expression in Escherichia Coli, and Epitope Analysis of a Two EF-Hand Calcium-Binding Birch Pollen Allergen, Bet V 4. Biochem Biophys Res Commun (1997) 239(1):197-204. doi: 10.1006/ bbrc. 1997.6860

78. Valenta R, Hayek B, Seiberler S, Bugajska-Schretter A, Niederberger V, Twardosz A, et al. Calcium-Binding Allergens: From Plants to Man. Int Arch Allergy Immunol (1998) 117(3):160-6. doi: 10.1159/000024005

79. Aalberse RC, Akkerdaas J, van Ree R. Cross-Reactivity of IgE Antibodies to Allergens. Allergy (2001) 56(6):478-90. doi: 10.1034/j.1398-9995.2001. 056006478.x
80. van der Veen MJ, van Ree R, Aalberse RC, Akkerdaas J, Koppelman SJ, Jansen HM, et al. Poor Biologic Activity of Cross-Reactive IgE Directed to Carbohydrate Determinants of Glycoproteins. J Allergy Clin Immunol (1997) 100(3):327-34. doi: 10.1016/s0091-6749(97)70245-8

81. Spitzauer S, Pandjaitan B, Söregi G, Mühl S, Ebner C, Kraft D, et al. IgE CrossReactivities Against Albumins in Patients Allergic to Animals. J Allergy Clin Immunol (1995) 96(6 Pt 1):951-9. doi: 10.1016/s0091-6749(95)70233-4

82. Karsonova AV, Riabova KA, Khaitov MR, Elisyutina OG, Ilina N, Fedenko ES, et al. Milk-Specific IgE Reactivity Without Symptoms in Albumin-Sensitized Cat Allergic Patients. Allergy Asthma Immunol Res (2021) 13:e66. doi: 10.4168/aair.2021.13.4.668

83. Apostolovic D, Sánchez-Vidaurre S, Waden K, Curin M, Grundström J, Gafvelin G, et al. The Cat Lipocalin Fel D 7 and Its Cross-Reactivity With the Dog Lipocalin Can F 1. Allergy (2016) 71(10):1490-5. doi: 10.1111/all.12955

84. Yamamoto K, Ishibashi O, Sugiura K, Ubatani M, Sakaguchi M, Nakatsuji M, et al. Crystal Structure of the Dog Allergen Can F 6 and Structure-Based Implications of Its Cross-Reactivity With the Cat Allergen Fel D 4. Sci Rep (2019) 9(1):1503. doi: 10.1038/s41598-018-38134-w

85. Reese G, Ayuso R, Lehrer SB. Tropomyosin: An Invertebrate Pan-Allergen. Int Arch Allergy Immunol (1999) 119(4):247-58. doi: 10.1159/000024201

86. Ruethers T, Taki AC, Johnston EB, Nugraha R, Le TTK, Kalic T, et al. Seafood Allergy: A Comprehensive Review of Fish and Shellfish Allergens. Mol Immunol (2018) 100:28-57. doi: 10.1016/j.molimm.2018.04.008

87. Binder M, Mahler V, Hayek B, Sperr WR, Schöller M, Prozell S, et al. Molecular and Immunological Characterization of Arginine Kinase From the Indianmeal Moth, Plodia Interpunctella, a Novel Cross-Reactive Invertebrate Pan-Allergen. J Immunol (2001) 167(9):5470-7. doi: 10.4049/ jimmunol.167.9.5470

88. Sarzsinszky E, Lupinek C, Vrtala S, Huang HJ, Hofer G, Keller W, et al. Expression in Escherichia Coli and Purification of Folded Rder P 20, the Arginine Kinase From Dermatophagoides Pteronyssinus: A Possible Biomarker for Allergic Asthma. Allergy Asthma Immunol Res (2021) 13 (1):154-63. doi: 10.4168/aair.2021.13.1.154

89. O'Neill GM, Donovan GR, Baldo BA. Cloning and Characterization of a Major Allergen of the House Dust Mite, Dermatophagoides Pteronyssinus, Homologous With Glutathione S-Transferase. Biochim Biophys Acta (1994) 1219(2):521-8. doi: 10.1016/0167-4781(94)90080-9

90. Mueller GA, Pedersen LC, Glesner J, Edwards LL, Zakzuk J, London RE, et al. Analysis of Glutathione S-Transferase Allergen Cross-Reactivity in a North American Population: Relevance for Molecular Diagnosis. J Allergy Clin Immunol (2015) 136(5):1369-77. doi: 10.1016/j.jaci.2015.03.015

91. Huang HJ, Campana R, Akinfenwa O, Curin M, Sarzsinszky E, Karsonova A, et al. Microarray-Based Allergy Diagnosis: Quo Vadis? Front Immunol (2021) 11:594978. doi: 10.3389/fimmu.2020.594978

92. Simpson A, Lazic N, Belgrave DC, Johnson P, Bishop C, Mills C, et al. Patterns of IgE Responses to Multiple Allergen Components and Clinical Symptoms at Age 11 Years. J Allergy Clin Immunol (2015) 136(5):1224-31. doi: 10.1016/ j.jaci.2015.03.027

93. Elisyutina O, Fedenko E, Campana R, Litovkina A, Ilina N, Kudlay D, et al. Bet V 1-Specific IgE Levels and PR-10 Reactivity Discriminate Silent Sensitization From Phenotypes of Birch Allergy. Allergy (2019) 74(12):2525-8. doi: 10.1111/all.13931

94. Lupinek C, Marth K, Niederberger V, Valenta R. Analysis of Serum IgE Reactivity Profiles With Microarrayed Allergens Indicates Absence of De Novo IgE Sensitizations in Adults. J Allergy Clin Immunol (2012) 130(6):141820.e4. doi: $10.1016 /$ j.jaci.2012.06.028

95. Wollmann E, Hamsten C, Sibanda E, Ochome M, Focke-Tejkl M, Asarnoj A, et al. Natural Clinical Tolerance to Peanut in African Patients Is Caused by Poor Allergenic Activity of Peanut IgE. Allergy (2015) 70(6):638-52. doi: $10.1111 /$ all.12592

96. Asher MI, Keil U, Anderson HR, Beasley R, Crane J, Martinez F, et al. International Study of Asthma and Allergies in Childhood (ISAAC): Rationale and Methods. Eur Respir J (1995) 8(3):483-91. doi: 10.1183/09031936. 95.08030483

97. Fontanella S, Frainay C, Murray CS, Simpson A, Custovic A. Machine Learning to Identify Pairwise Interactions Between Specific IgE Antibodies and Their Association With Asthma: A Cross-Sectional Analysis Within a Population-Based Birth Cohort. PloS Med (2018) 15(11):e1002691. doi: 10.1371/journal.pmed.1002691 
98. Niespodziana K, Borochova K, Pazderova P, Schlederer T, Astafyeva N, Baranovskaya $\mathrm{T}$, et al. Toward Personalization of Asthma Treatment According to Trigger Factors. J Allergy Clin Immunol (2020) 145(6):152934. doi: 10.1016/j.jaci.2020.02.001

Conflict of Interest: RV has received research grants from HVD Life Science, Vienna Austria, Viravaxx, Vienna, Austria and Worg Pharmaceuticals, Hangzhou, China and serves as a consultant for Viravaxx and Worg. YL and RJ are employees of Worg Pharmaceuticals.

The remaining authors declare that the research was conducted in the absence of any commercial or financial relationships that could be construed as a potential conflict of interest.
Publisher's Note: All claims expressed in this article are solely those of the authors and do not necessarily represent those of their affiliated organizations, or those of the publisher, the editors and the reviewers. Any product that may be evaluated in this article, or claim that may be made by its manufacturer, is not guaranteed or endorsed by the publisher.

Copyright (C) 2021 D'souza, Weber, Sarzsinszky, Vrtala, Curin, Schaar, Garib, Focke-Tejkl, Li, Jones, Chen, Valenta and Sun. This is an open-access article distributed under the terms of the Creative Commons Attribution License (CC BY). The use, distribution or reproduction in other forums is permitted, provided the original author(s) and the copyright owner(s) are credited and that the original publication in this journal is cited, in accordance with accepted academic practice. No use, distribution or reproduction is permitted which does not comply with these terms. 